\title{
Review Article \\ Overcome Cancer Cell Drug Resistance Using Natural Products
}

\author{
Pu Wang, Hua Li Yang, Ying Juan Yang, Lan Wang, and Shao Chin Lee
}

School of Life Sciences, Shanxi University, Taiyuan, Shanxi 030006, China

Correspondence should be addressed to Shao Chin Lee; lee_shao@hotmail.com

Received 17 May 2015; Revised 12 July 2015; Accepted 30 July 2015

Academic Editor: Yew-Min Tzeng

Copyright (C) $2015 \mathrm{Pu}$ Wang et al. This is an open access article distributed under the Creative Commons Attribution License, which permits unrestricted use, distribution, and reproduction in any medium, provided the original work is properly cited.

\begin{abstract}
Chemotherapy is one of the major treatment methods for cancer. However, failure in chemotherapy is not uncommon, mainly due to dose-limiting toxicity associated with drug resistance. Management of drug resistance is important towards successful chemotherapy. There are many reports in the Chinese literature that natural products can overcome cancer cell drug resistance, which deserve sharing with scientific and industrial communities. We summarized the reports into four categories: (1) in vitro studies using cell line models; (2) serum pharmacology; (3) in vivo studies using animal models; and (4) clinical studies. Fourteen single compounds were reported to have antidrug resistance activity for the first time. In vitro, compounds were able to overcome drug resistance at nontoxic or subtoxic concentrations, in a dose-dependent manner, by inhibiting drug transporters, cell detoxification capacity, or cell apoptosis sensitivity. Studies in vivo showed that single compounds, herbal extract, and formulas had potent antidrug resistance activities. Importantly, many single compounds, herbal extracts, and formulas have been used clinically to treat various diseases including cancer. The review provides comprehensive data on use of natural compounds to overcome cancer cell drug resistance in China, which may facilitate the therapeutic development of natural products for clinical management of cancer drug resistance.
\end{abstract}

\section{Introduction}

Cancer is one of the most common noncommunicable diseases and one of the leading causes of death worldwide, with approximately 14 million new cases and 8.2 million cancerrelated deaths in 2012, which are expected to rise in the future [1]. In China, according to the Annual Cancer Registry in 2013, more than 3 million new cases were diagnosed with cancer, which is equivalent to 6 patients diagnosed per minute, and the prevalence has been increasing. This casts great socioeconomic burdens. Despite the fact that chemotherapy is central to clinical management of cancer, failure in chemotherapy is not uncommon, mainly due to the dose-limiting toxicities, which is associated with the occurrence of drug resistance. Cancer cell drug resistance occurs in inherited or acquired manners. Inherited drug resistance is the initial unresponsiveness of cancer to a specific drug, while acquired resistance refers to emerged drug resistance after initial successful drug treatment. No matter whether it occurs before or after chemotherapy, how to overcome drug resistance is a key issue for cancer management, which has been under investigation. Taking nanomedicine, for example, scientists have been trying to deliver drugs to cancer cells by nanoparticles, which may provide an approach to overcome drug resistance [2], as nanoparticles are hoped to enhance drug permeability, retention, and intracellular accumulation as well as increase drug circulating time. Amongst various nanoparticles, ThermoDox is currently under phase III clinical trial, which is a type of lipid-based nanoparticle that uses polyethylene glycol to increase circulation time. There are also clinical trials that use dendrimers to deliver chemodrug to treat different cancers such as breast cancer, non-small cell lung cancer, and advanced pancreatic cancer. Apart from the modern technologies, use of chemical compounds to counteract drug resistance is another strategy, for which natural products may be useful. Indeed, natural products provide a useful resource for drug development. About $36 \%$ of the small molecule compounds approved by US Food and Drug Administration between 1999 and 2008 are natural products or their derivatives [3]. In the past years, there is an emerging view that targeted therapies are superior to traditional chemotherapy, which seems to 
promote the development of targeted therapy, leaving the therapeutic development of natural compounds more or less being ignored. Unfortunately, the drawbacks of targeted therapy start to appear after years in practice [4]. Majority of cancers are not targetable, as they show disturbances in multiple oncogenic pathways and adaptive mechanisms that limit the efficacy of targeted therapy, and the treatment benefit using targeted therapy is often less than 6 months. Combination treatment using multiple targeted therapeutic agents may not be better; it can have greater unacceptable toxicity than clinical benefits. Thus, the natural products have come back to the spot light in the area of cancer management; 12 natural products and derivatives have been approved for cancer treatment since 2007. Some natural compounds such as quercetin and curcumin are under clinical trials to overcome cancer drug resistance [5]. In China, in particular, possibly due to the long history of using natural compounds in clinical management of disease including cancer, as is practiced in Traditional Chinese Medicine, there are many reports on overcoming cancer drug resistance using natural compounds. These investigations have produced abundant informative data, which are unlikely to be commonly known to other scientific and industrial communities. Sharing the information is likely to be appreciated.

This review summarizes and discusses the studies on the use of natural products to overcome cancer drug resistance, which were published in the Chinese literature. These studies are organized into four categories: (1) in vitro studies using various cell line models; (2) serum pharmacology studies that test the antidrug resistance effects of serum samples from animals fed with natural products; (3) in vivo studies that use animal models bearing tumor xenografts or transplantable tumor cells; and (4) clinical studies that give natural products to patients in addition to conventional chemotherapy, in comparison with patients who receive conventional chemotherapy alone.

We are aware that there are many excellent works in this area published in English. They have been reviewed, including a review by Cort and Ozben this year [6]. There are also Chinese authors who publish reports in English rather than Chinese journals. For example, Zhang and coworker show that a synthetic derivative of 23-hydroxybetulinic acid can reverse cancer cell multidrug resistance [7]. Guo et al. note that $\beta$-Elemene can reverse multidrug resistance mediated by the ABCB1 transporter [8]. Moreover, marine drugs can provide promising candidates for reversal of cancer cell drug resistance, such as lamellarin $\mathrm{O}$ [9] and sipholenol A [10]. These informative data are not included in this review.

\section{Mechanisms of Drug Resistance}

Cancer chemoresistance occurs through various biological mechanisms that include drug efflux, inhibition of cell death, detoxification, DNA damage repair, alternation of drug targets, stem cells, and epithelial to mesenchymal transition $[11,12]$. Amongst these mechanisms, drug efflux, cell death inhibition, and detoxification are commonly studied, which are relevant to this review (Figure 1).

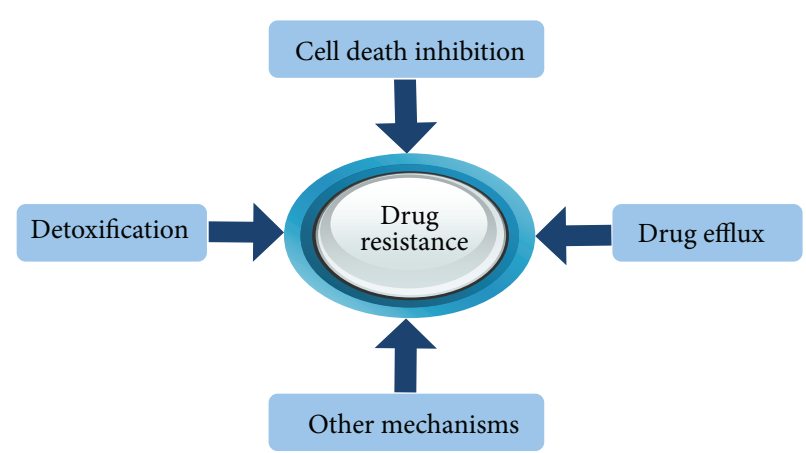

FIgURE 1: Mechanisms underlying the development of cancer cell drug resistance.

2.1. Drug Efflux. A family of proteins can expel drugs out of cancer cells and decrease the intracellular drug concentration, thereby preventing the drug toxicity. The human genome encodes 48 members of such proteins called ATPbinding cassettes $(\mathrm{ABC})$, which fall into $\mathrm{ABCA}$ to $\mathrm{ABCG}$ 7 subgroups, with 15 of them being associated with drug resistance. These proteins are believed to be the major players in the development of cancer cell chemoresistance [13]. The best characterized ABC proteins are MDR1 (p-glycoprotein), multidrug resistance-associated proteins (MRPs), and breast cancer resistant protein (BCRP). MDR1 is the first ABC member discovered with a role in drug resistance. It is expressed in nearly all tissues and has been found to mediate drug resistance in many cancers including breast, colon, gastric, kidney, leukemic, liver, and pancreatic cancer [14]. MRPs represent the largest branch of $\mathrm{ABC}$ transporters. This subgroup of proteins includes nine efflux transporters (MRPs1-9), one gated chloride channel, and two potassium channel regulators [8], with MRP1 as the founding member. MRP1 is ubiquitously found in a number of human cells, the elevation of which is associated with drug resistance in many types of cancer. BCRP was first cloned from drug resistant human breast cancer cells, whereby it gets the name [15], which is expressed in many types of cells [16].

2.2. Inhibition of Cell Death. Apoptosis is the major type of cell death triggered by chemodrugs. There are two established pathways of apoptosis. The intrinsic pathway centers on mitochondria. Apoptotic signals recruit proapoptotic molecules such as Bax to mitochondria, followed by triggering mitochondria to release cytochrome $c$ that leads to activation of downstream caspases which are apoptosis effectors to cause cell damage. There are also antiapoptotic factors that play an important part in the decision of life or death, which include Bcl-2 and Akt. Bcl-2 is located on mitochondria, which can inhibit cytochrome c release. The extrinsic pathway is activated by binding of ligand to death receptor on cell surface, which activates caspase- 8 and then downstream caspases. Bcl-2 and Akt as well as NF- $\kappa \mathrm{B}$ are found to be highly expressed in some type of cancers, which are associated with drug resistance. Akt itself is a protein kinase which is activated by PI3 kinase. Once activated, Akt can regulate a variety of apoptosis signal mediators to inhibit apoptosis. 
It can phosphorylate $\mathrm{I} \kappa \mathrm{B}$, which results in $\mathrm{NF} \kappa \mathrm{B}$ activation that promotes survival and Bad phosphorylation/inactivation to block apoptotic signal. In addition, phosphorylation of caspase- 9 by Akt also blocks the induction of apoptosis, and both Akt and $\mathrm{NF} \kappa \mathrm{B}$ can activate $\mathrm{Bcl}-2$ to inhibit cytochrome $\mathrm{c}$ release from mitochondria [17]. Suppression of proapoptotic proteins such as Bax is also associated with the occurrence of drug resistance. In the clinical setting, upregulation of antiapoptotic proteins (i.e., Bcl-2) and downregulation of proapoptotic proteins (i.e., Bax) are found to be associated with poor prognosis of cancer patients [11,18], which supports a causal role of apoptosis inhibition in the occurrence of cancer cell drug resistance.

2.3. Detoxification. GSH-GST system is one of the major detoxification mechanisms, which is in relevance to the development of drug resistance [19]. Levels of GSH and GST activity are in positive correlation with cancer stage [20]. Protein level of GST $\pi$, in particular, is found to be associated with chemoresistance in patients with different cancers [2123]. In the clinical setting, GST gene polymorphisms are associated with the development of different cancers [24] and the response of cancer patients to chemotherapy [25]. These observations support a role of GSH-GST system in the regulation of cancer cell response to chemodrugs.

GSH is a small peptide composed of glutamate, cysteine, and glycine. It is an important cellular antioxidant that can suppress oxidative stress to maintain normal cellular redox homeostasis, which relies on its conjugation properties of the sulfhydryl moiety of the cysteine residue. GSH has the ability to directly scavenge cellular reactive oxygen species in a nonenzymatic manner. Alternatively, it serves as a cofactor for GSH peroxidase in the reduction of $\mathrm{H}_{2} \mathrm{O}_{2}$ and other peroxide species. The GSTs are classical phase II metabolic enzymes including GST $\pi$. They can detoxify xenobiotics via conjugation of reduced GSH with the electrophilic center of a large spectrum of hydrophilic molecules. Although GSH-GST system helps in the maintenance of normal redox homeostasis and the protection against oxidative damage, it has adverse effect in chemotherapy, as it is also intimately involved in the detoxification of numerous xenobiotics. GST family of enzymes utilize GSH as a cofactor in the phase II metabolism of various chemotherapeutic agents, resulting in the formation of GSH-drug conjugates that are more water soluble than their parent compounds and therefore are easier for transporter-mediated efflux. Unfortunately, many chemodrugs are substrates of GSTs. This explains why elevated level/activity of intracellular GSH-GST system is often implicated in the development of cancer cell resistance to various chemodrugs [2].

\section{Natural Products Overcome Cancer Cell Drug Resistance on Cell Line Models through Various Molecular Mechanisms}

Chinese people have been treating diseases using Traditional Chinese Medicine for long, which typically involves the use of natural products in addition to acupuncture, moxibustion, and physiotherapy. Possibly due to this heritage, we are keen to use natural products to overcome cancer cell drug resistance. Wang and coworkers [26] treated bladder cancer T24/ADM cells by doxorubicin with or without osthole. They found that the IC50 of osthole was $76.5 \mu \mathrm{M}$ and it was not toxic to the cells at the concentrations of $17 \mu \mathrm{M}$ or below. However, at $17 \mu \mathrm{M}$, it was able to lower the IC50 of doxorubicin from 1.0 to $0.4 \mu \mathrm{M}$, resulting in an increase of drug sensitivity by 2.5 times. Nong and coworker [27] investigated the antidrug resistance effects of evodiamine using A549/DDP cell line. The compound was not toxic to both resistant and sensitive (A549) cells at the concentrations of $5 \mu \mathrm{g} / \mathrm{mL}$ or below. At $0.25 \mu \mathrm{g} / \mathrm{mL}$, it lowered the IC50 of cisplatin from 76.7 to $6.7 \mu \mathrm{g} / \mathrm{mL}$, resulting in an increase in the drug sensitivity of A549/DDP cells by 11.4 times. In mechanistic analysis, the authors found that evodiamine was able to decrease the mRNA levels of MDR1 and Bcl-2 and decrease the level of pIKK $\alpha$, indicating that the compound acts on multiple pathways to overcome drug resistance. Celastrol also has significant antidrug resistance activity. In K562/A02 cells, it can increase the cell sensitivity to chemodrug by 117.9 times, concomitantly with a significant increase in intracellular drug concentration and a decrease in MDR1 protein level [28]. In another study, embelin was found to increase the sensitivity of drug resistant K562 cells to daunorubicin by 7.5 times [29].

There are many more studies using cell line models to test the antidrug resistance activity of natural products. Some studies focus on antidrug resistance effect of compounds without examining the underlying mechanisms (Table 1). Some others investigate the antidrug resistance activity of natural products and the mechanism of drug efflux (Table 2) or inhibition of apoptosis (Table 3). There are natural products that can overcome drug resistance and regulate different pathways, suggesting that they act on multiple molecules to achieve their biological activity (Table 4 ). Moreover, some compounds are found to target GSH-GST system. These include arsenic trioxide [30], neferine [31], quercetin [32], emodin [33], irisquinone [34], tetramethylpyrazine [35], and ganoderma lucidum polysaccharides [36].

Fourteen single compounds are shown to be able to overcome cancer cell drug resistance for the first time. These include evodiamine, peiminine, isorhynchophylline, berberine, ephedrine, ginsenoside Rbl, oridonin, oxymatrine, methylether-scutellarein, sodium norcantharidate, phenylpropanoid glycoside, retinoic acid, schizandrin A, and baicalin (Tables 1-4), which deserve further investigations. Also for the first time, the studies have revealed the antidrug resistance activities of the various herbal extracts (Tables 1-4).

Some of these compounds (Tables 1-4) are in clinical use for the management of various diseases. For example, oxymatrine is in clinical use to suppress replication of hepatitis $B$ virus [37] and prevent hepatic fibrosis [38]. Berberine is commonly used to treat bacterial and viral infections as well as to increase insulin sensitivity and lower the level of blood sugar [39]. Ephedrine is used to regulate blood pressure [40]. Sodium norcantharidate is used alone or in combination with other established chemotherapeutic drugs to treat cancers [41]. Baicalin is useful in treating psoriasis [42]. 
TABLE 1: Natural products that can overcome drug resistance without mechanistic information.

\begin{tabular}{|c|c|c|c|c|c|}
\hline Compound name & Dose & Cell model & Chemodrug & IDS $^{1}$ & Reference \\
\hline \multicolumn{6}{|l|}{ Single compound } \\
\hline $4^{\prime}$-Methylether-scutellarein & $20 \mu \mathrm{g} / \mathrm{mL}$ & JAR/VP16 & Etoposide & 5.0 & {$[61]$} \\
\hline Dauricine & $2.5 \mu \mathrm{g} / \mathrm{mL}$ & K562/ADM & Doxorubicin & 5.0 & {$[62]$} \\
\hline Dihydroartemisinin & $0.3 \mu \mathrm{M}$ & A549/CDDP & Cisplatin & 12.3 & {$[63]$} \\
\hline Ginsenoside Rh2 & $40 \mu \mathrm{M}$ & $\mathrm{MCF} / \mathrm{ADM}$ & Doxorubicin & 31.1 & {$[64]$} \\
\hline Isorhynchophylline & $1.5-3 \mu \mathrm{g} / \mathrm{mL}$ & A549/DDP & Various & $7.2-24.3$ & {$[65-67]$} \\
\hline Ligustrazine & $2.6-10 \mu \mathrm{g} / \mathrm{mL}$ & K562/ADM & Doxorubicin & $6.0-178$ & {$[68,69]$} \\
\hline Matrine & $50 \mu \mathrm{g} / \mathrm{mL}$ & K562/ADM & Doxorubicin & 2.2 & {$[70]$} \\
\hline Peiminine & $20 \mu \mathrm{g} / \mathrm{mL}$ & SGC7901/VCR & Various & $6-27$ & {$[71]$} \\
\hline Schizandrol A & $25 \mu \mathrm{M}$ & HL60/ADR & Daunorubicin & 8 & {$[72]$} \\
\hline Tanshinone II A & $0.2 \mu \mathrm{g} / \mathrm{mL}$ & $\mathrm{MCF} / \mathrm{ADM}$ & Doxorubicin & 2.5 & {$[73]$} \\
\hline \multicolumn{6}{|l|}{ Single herb extract } \\
\hline Eleutherococcus senticosus & $200 \mu \mathrm{g} / \mathrm{mL}$ & K562/ADR & Daunomycin & 4.2 & {$[74]$} \\
\hline Andrographis paniculata & $2.4 \mu \mathrm{g} / \mathrm{mL}$ & СHT8/5FU & Various & $2.1-2.2$ & {$[75]$} \\
\hline Indigowoad root & $31 \mu \mathrm{g} / \mathrm{mL}$ & BEL7404/ADM & Doxorubicin & 4.8 & {$[76]$} \\
\hline \multicolumn{6}{|l|}{ Formula extract } \\
\hline Danggui Buxue recipe & $300 \mu \mathrm{g} / \mathrm{mL}$ & SGC7901/ADR & Doxorubicin & 2.8 & {$[77]$} \\
\hline Fufang Jinzi recipe & $5 \mu \mathrm{g} / \mathrm{mL}$ & K562/VCR & Vincristine & 3.6 & {$[78]$} \\
\hline
\end{tabular}

${ }^{1}$ IDS, increase in drug sensitivity ( $x$-fold).

IDS = IC50 in control group/IC50 in experimental group.

Some information has not been included in Tables 14, which deserves specification: (1) in the reviewed studies (Tables 1-4), the compounds are commonly used in notoxic or subtoxic concentrations; (2) the tested compounds can overcome drug resistance in a dose-dependent manner; (3) in some but not all studies, it has been shown that the drug resistance-related genes/proteins are upregulated in drug resistant cells compared to their drug sensitive counterparts, and the tested compounds lower the expression level of the drug resistance-associated genes/proteins in the resistant cells; (4) the tested compounds largely increase drug sensitivity of resistant cells, with no or weak effect on the drug sensitive counterparts, which suggests that the antidrug resistance activity of the compounds has a specificity; (5) some studies have demonstrated the antidrug resistance effects of the natural products on multiple cell line models treated with different chemodrugs; and (6) all of the mentioned herbs and some of the single compounds have been used in clinical settings in China in treating various diseases, which is not further discussed in detail.

\section{Serum Pharmacology}

Compounds are introduced to cell culture in the in vitro studies, and their actions may be different when they are applied in vivo, since they will be subjected to metabolism in the latter condition. Serum pharmacological study provides a mean to address the issue, at least in part [43]. In this type of assay, animals are fed with compounds or herbal extracts over a short period of time, and serum samples are collected for bioactivity assay in vitro on cell line models.
The outcomes are more likely to represent the bioactivity of compounds in vivo. Usually, compounds are given to animal in an amount equivalent to that used in humans in terms of quantity per unit of body weight. Serum is often applied to cell culture at the concentrations between 5 and $20 \%$ in volume. At least 52 serum pharmacology studies are recorded in the Chinese database used for information acquisition, all of which use extract of herbal formulas, except one that uses extract of single herb extract, possibly due to the reason that herbal formulas rather than single herb are commonly used in the practice of Traditional Chinese Medicine. Deng and coworkers [44] investigated the antidrug resistance effect of Changweiqing. They fed rats with Changweiqing extract for 5 days and collected serum samples. In control groups, rats were given saline. The serum samples from the rats in the experimental group were found to be able to increase the sensitivity of drug resistant HCT8/V cells to cisplatin by 13 times in vitro. The antidrug resistance effect of Changweiqing serum has also been observed on oral epidermoid carcinoma cell line KB-A-1. It increased the sensitivity of the drug resistant cells to doxorubicin in a dose-dependent manner, which reached 5.2 times at the concentration of $5 \%$ in cell culture medium [45]. Wenxia formula is another formula that can overcome drug resistance. Serum from animals fed with this formula extract can increase the sensitivity of A549/DDP cells to cisplatin by 2.5 times [46]. Five more serum pharmacology studies are listed in Table 5. The herbal compositions of these formulas are listed in Table 7. Moreover, these formulas have been used in the clinical setting in China to treat various diseases. Changweiqing, for example, is in clinical use to treat constipation [47], infection of Helicobacter pylori [48], and chronic gastritis [49]. 
TABLE 2: Natural products that can overcome drug resistance and inhibit drug transporters.

\begin{tabular}{|c|c|c|c|c|c|c|}
\hline Compound name & Dose & Drug target $^{1}$ & Cell model & Chemodrug & IDS $^{2}$ & Reference \\
\hline \multicolumn{7}{|l|}{ Single compound } \\
\hline Apigenin & $15 \mu \mathrm{M}$ & MDR1 & $\mathrm{HCT} / 5 \mathrm{FU}$ & 5-Fluorouracil & 5.8 & {$[79]$} \\
\hline Arsenic Trioxide & $0.15-0.4 \mu \mathrm{M}$ & MDR1 and MRP & Various & Various & $2.1-3.0$ & [80-82] \\
\hline Artemisinin & $40 \mu \mathrm{M}$ & MDR1 & MCF7/ADR & Doxorubicin & 3.6 & [83] \\
\hline Artesunate & $20 \mu \mathrm{g} / \mathrm{mL}$ & MDR1 & SP2/0/ADM & Doxorubicin & 4.2 & {$[84]$} \\
\hline Baicalin & $20-300 \mu \mathrm{g} / \mathrm{mL}$ & MDR1 and MRP1 & Various & Doxorubicin & $6.3-7.8$ & {$[85,86]$} \\
\hline Berbamine & $20 \mu \mathrm{M}$ & MDR1 & MCF7/ADR & Doxorubicin & 28.3 & {$[87]$} \\
\hline Berberine & $20 \mu \mathrm{M}$ & MDR1 & HCT8/VCR & Vincristine & 3.6 & {$[88]$} \\
\hline Carnosic acid & $5 \mu \mathrm{g} / \mathrm{mL}$ & MDR1 & K562/A02 & Doxorubicin & 12.1 & [89] \\
\hline Chelerythrine & $0.1 \mu \mathrm{M}$ & MDR1 & MCF7/Taxel & Paclitaxel & 5.9 & {$[90]$} \\
\hline Curcumin & $2.5-25 \mu \mathrm{M}$ & MDR1 & Various & Various & $4.6-4.8$ & {$[91,92]$} \\
\hline Elemene & $4-18 \mu \mathrm{g} / \mathrm{mL}$ & MDR1 and MRP & Various & Various & $3.1-4.1$ & [93-95] \\
\hline Ephedrine & $75 \mu \mathrm{g} / \mathrm{mL}$ & MDR1 & K562/A02 & Daunorubicin & 5.7 & [96] \\
\hline Epigallocatechin gallate & $2-80 \mu \mathrm{M}$ & MDR1 and ABCG2 & Various & Various & $2.7-24.2$ & {$[97,98]$} \\
\hline Gambogic acid & $4 \mu \mathrm{g} / \mathrm{mL}$ & MDR1 & SW480/L-OHP & Oxaliplatin & 3.7 & [99] \\
\hline Ginsenoside Rb1 & $80 \mu \mathrm{M}$ & MDR1 & HL60/VCR & Vincristine & 2.7 & {$[100]$} \\
\hline Ginsenoside Rg3 & $10-40 \mu \mathrm{g} / \mathrm{mL}$ & MDR1, MRP, and LRP & Various & Various & $7.3-11$ & {$[101,102]$} \\
\hline Neferine & $10-20 \mu \mathrm{M}$ & MDR1 and MRP & SGC7901/VCR & Various & $3.3-43.8$ & [103-105] \\
\hline Oridonin & $3 \mu \mathrm{M}$ & MDR1 & K562/A02 & Various & 9.2 & {$[106]$} \\
\hline Oxymatrine & $0.8 \mathrm{mg} / \mathrm{mL}$ & MDR1 & MCF7/ADM & Doxorubicin & 3.3 & [107] \\
\hline Peimine & $400 \mu \mathrm{g} / \mathrm{mL}$ & LRP & A549/DDP & Cisplatin & 3.7 & {$[108]$} \\
\hline Psoralen & $20 \mu \mathrm{g} / \mathrm{mL}$ & MDR1 & MCF7/ADR & Doxorubicin & 11.8 & [109] \\
\hline Quercetin & Various & MDR1 and MRP1 & Various & Various & $2.3-22.0$ & {$[110,111]$} \\
\hline Sodium norcantharidate & $5 \mu \mathrm{g} / \mathrm{mL}$ & MDR1 and MRP & A549/DPP & Cisplatin & 2.0 & {$[112]$} \\
\hline Tetramethylpyrazine & $200-320 \mu \mathrm{g} / \mathrm{mL}$ & MDR1 & Various & Doxorubicin & $2.1-5.2$ & [113-115] \\
\hline Tetrandrine & $1 \mu \mathrm{M}$ & MDR1 & Hep3B/ADM & Doxorubicin & 12.7 & {$[116]$} \\
\hline \multicolumn{7}{|l|}{ Single herbal extract } \\
\hline Brucea Javanica & $55.3-125 \mu \mathrm{g} / \mathrm{mL}$ & MDR1 and MRP & Various & Various & $2.1-5.8$ & {$[117,118]$} \\
\hline Cinobufacini & $?$ & MDR1 and MRP1 & Raji/ADR & Doxorubicin & 255.7 & [119] \\
\hline Grape seed polyphenols & $2.4-6.0 \mu \mathrm{g} / \mathrm{mL}$ & MDR1 & Various & Various & $3.4-4.5$ & {$[120,121]$} \\
\hline Hyaluronate Oligomers & $100 \mu \mathrm{g} / \mathrm{mL}$ & MDR1 and MRP & MCF7/ADM & Doxorubicin & 2.0 & {$[122]$} \\
\hline Jew ear & $8-10 \mu \mathrm{g} / \mathrm{mL}$ & MDR1 and MRP & Various & Various & $2.2-5.6$ & {$[123-125]$} \\
\hline Radix notoginseng & $200 \mu \mathrm{g} / \mathrm{mL}$ & MDR1 & Various & Various & 5.6 & {$[126,127]$} \\
\hline Rhizoma pinelliae & $6.5 \mu \mathrm{g} / \mathrm{mL}$ & MDR1 & K562/A02 & Doxorubicin & 3.6 & [128] \\
\hline Realgar & $25 \mu \mathrm{g} / \mathrm{mL}$ & MDR1 & MCF7/ADM & Doxorubicin & 2.8 & [129] \\
\hline Thallus laminariae & $70-78 \mu \mathrm{g} / \mathrm{mL}$ & MDR1 & Various & Doxorubicin & $4.7-5.0$ & {$[130,130]$} \\
\hline
\end{tabular}

${ }^{1}$ Levels of protein or mRNA or both were quantified.

${ }^{2}$ IDS, increase in drug sensitivity $(x$-fold).

IDS = IC50 in control group/IC50 in experimental group.

\section{Overcome Drug Resistance in Animal Models}

Since many natural compounds can overcome cancer cell drug resistance in vitro (Tables 1-4), it is logical to ask whether the bioactivities can be replicated in vivo, that is, in animal models. Indeed, the effects have been shown in a number of studies in animal models. Zhang and coworker [50] built an experimental model of nude mice with xenograft of drug resistant HCT116/L-OHP cells and divided the mice into two groups. One was treated with oxaliplatin, which serves as the control. In the experimental group, mice were treated with oxaliplatin plus Changweiqing extract, 5 times a week for 3 weeks. Compared with the tumor size in the controls, The tumor size in mice treated with Changweiqing was reduced by 3.1 times on average, compared with that in the controls. Feng and coworker [51] treated mice bearing xenograft of drug resistant MCF-7/ADM cells with doxorubicin (control group) or doxorubicin plus extract of Huatan Sanjie formula (experimental group). Herbal extract was applied only twice, at days 8 and 15, respectively. At day 17, mice were sacrificed and tumor tissues were dissected. Compared to the controls, the mice in the experimental group had decreased in tumor tissue weight by 4.8 -fold. Interestingly, the tumor tissues 
TABLE 3: Natural products that can overcome drug resistance and inhibit apoptosis signaling.

\begin{tabular}{|c|c|c|c|c|c|c|}
\hline Compound name & Dose & Drug target $^{1}$ & Model cell & Chemodrug & IDS $^{2}$ & Reference \\
\hline \multicolumn{7}{|l|}{ Single compound } \\
\hline Curcumin & $10 \mu \mathrm{M}$ & Caspase-3 & HCT8/5FU & 5-Fluorouracil & 10.1 & {$[131]$} \\
\hline Dihydroartemisinin & $230 \mathrm{nM}$ & Bcl-2, Bax, and Caspase- 3 & A549/DDP & Cisplatin & 8.3 & {$[132]$} \\
\hline Elemene & $10-30 \mu \mathrm{g} / \mathrm{mL}$ & GSH, Bcl-2, and Bad & Various & Various & $2.2-3.7$ & [133-135] \\
\hline Emodin & $30 \mu \mathrm{M}$ & p-EGFR and p-ERK & HCC827/GR & Gefitinib & 6.0 & [136] \\
\hline Epigallocatechin gallate & $80 \mu \mathrm{M}$ & Bcl-2 and Bax & K562/A02 & Doxorubicin & 24.2 & [137] \\
\hline Ginsenoside Rh2 & $10 \mu \mathrm{M}$ & & A549/DDP & Cisplatin & 3.5 & [138] \\
\hline Neferine & $10 \mu \mathrm{M}$ & $\mathrm{Bcl}-2$ & SGC7901/VCR & Vincristine & 43.8 & [139] \\
\hline Parthenolide & $20 \mu \mathrm{M}$ & Survivin and Bcl-2 & A549/GR & Gefitinib & 8.7 & [140] \\
\hline Phenylpropanoid glycoside & $40 \mu \mathrm{g} / \mathrm{mL}$ & Caspase-3 & LoVo/ADR & Doxorubicin & 9.9 & [141] \\
\hline Retinoic acid & $1 \mu \mathrm{M}$ & Bcl-2 & MCF7/TAM & Tamoxifen & 6.7 & [142] \\
\hline Tetrandrine & $1.0 \mu \mathrm{g} / \mathrm{mL}$ & Bcl-2 and Bax & BIU-87/ADM & Doxorubicin & 2.2 & [143] \\
\hline \multicolumn{7}{|l|}{ Herbal extract } \\
\hline Realgar & $15 \mu \mathrm{g} / \mathrm{mL}$ & $\mathrm{Bcl}-2$ & MCF7/ADM & Doxorubicin & 2.3 & [144] \\
\hline
\end{tabular}

${ }^{1}$ Levels of protein or mRNA or both were quantified.

${ }^{2}$ IDS, increase in drug sensitivity ( $x$-fold).

IDS $=$ IC50 in control group/IC50 in experimental group.

TABLE 4: Natural products that can overcome drug resistance and regulate multiple pathways.

\begin{tabular}{|c|c|c|c|c|c|c|}
\hline Compound name & Dose & Pathways $^{1}$ & Cell model & Chemodrug & IDS $^{2}$ & Reference \\
\hline \multicolumn{7}{|l|}{ Single compound } \\
\hline Arsenic trioxide & $0.8 \mu \mathrm{M}$ & MDR1 and GST- $\pi$ & SGC7901/ADR & Doxorubicin & 2.1 & {$[82]$} \\
\hline Berbamine & $20 \mu \mathrm{M}$ & MDR1 and survivin & K562/A02 & Doxorubicin & 41.2 & [145] \\
\hline Carnosic acid & $25 \mu \mathrm{M}$ & MDR1 and Bcl-2 & K562/A02 & Doxorubicin & 12.1 & [146] \\
\hline Curcumin & $25 \mu \mathrm{M}$ & MRP and $\mathrm{Bcl}-2$ & HL60/ADR & Doxorubicin & 4.2 & {$[147]$} \\
\hline Emodin & $10 \mu \mathrm{M}$ & MRP1, Topo II b, GST- $\pi$, and Bcl-2 & HL60/ADR & Doxorubicin & 4.1 & [148] \\
\hline Honokiol & $6.5 \mu \mathrm{g} / \mathrm{mL}$ & MDR1 and NFkB & U937/ADR & Doxorubicin & 2.2 & [149] \\
\hline Methylether-scutellarein & $20 \mu \mathrm{g} / \mathrm{mL}$ & $\mathrm{ABC}$ and apoptosis genes & JAR/VP16 & Various & $2.5-5.0$ & {$[150]$} \\
\hline Quercetin & $10 \mu \mathrm{g} / \mathrm{mL}$ & MDR1 and survivin & A549/DDP & Cisplatin & 3.5 & {$[151]$} \\
\hline Quercetin & $40 \mu \mathrm{M}$ & $\mathrm{ABC}, \mathrm{Bcl}-2$, and SLC genes & K562/A & Doxorubicin & 3.7 & {$[152]$} \\
\hline Quercetin & $40 \mu \mathrm{M}$ & MDR1, MRP, GST- $\pi$, and H-ras & Bel-FU & 5-Fluorouracil & 2.4 & {$[153]$} \\
\hline Schizandrin B & $10 \mu \mathrm{M}$ & MDR1, pPI3K, and pAKT & $\mathrm{U}-2 \mathrm{OS} / \mathrm{ADR}$ & Various & $2.3-2.9$ & {$[154]$} \\
\hline Schizandrin A & $50 \mu \mathrm{M}$ & MDR1 and GSH & Various & Various & $41.2-147.5$ & {$[155]$} \\
\hline Sodium selenite & $10 \mu \mathrm{M}$ & MDR and Bcl-2 & K562/ADR & Doxorubicin & 2.3 & [156] \\
\hline Tetrandrine & $1 \mu \mathrm{g} / \mathrm{mL}$ & MDR1, survivin, and caspase- 3 & BIU87/ADM & Doxorubicin & 5.3 & {$[157]$} \\
\hline \multicolumn{7}{|l|}{ Herbal extract } \\
\hline Radix bupleuri & $300 \mu \mathrm{g} / \mathrm{mL}$ & MDR1 and TopoII $\alpha$ & Bel-7402 & Verapamil & 15.6 & {$[158]$} \\
\hline Grape seed polyphenols & $6 \mu \mathrm{g} / \mathrm{mL}$ & MDR1 and Bcl-2 & $\mathrm{GBC} / \mathrm{SD}$ & Various & $3.4-4.5$ & [159] \\
\hline Tea polyphenols & $7.5 \mu \mathrm{g} / \mathrm{mL}$ & MRP and Bcl-2 & HL60/VCR & Various & $2.3-9.1$ & [160] \\
\hline
\end{tabular}

${ }^{1}$ Levels of protein or mRNA or both were quantified.

${ }^{2}$ IDS, increase in drug sensitivity ( $x$-fold).

IDS = IC50 in control group/IC50 in experimental group.

from the mice in the experimental group had increased level of doxorubicin and decreased protein level of MDR1. The data, taken together, suggest that the herbal extracts overcome the drug resistance of the tumor xenograft by inhibiting drug pump. In addition to herbal extracts, single compound is found to overcome drug resistance in vivo. In the in vitro study, epigallocatechin gallate $(30 \mu \mathrm{g} / \mathrm{mL})$ is not toxic to drug resistant KBV200 cells but increases their sensitivity to vincristine by 13 times, increases the intracellular vincristine concentration by 3 times, and reduces the intracellular MDR1 protein concentration. In mice model, the compound significantly increases the antitumor effect of vincristine and decreases the mRNA levels of MRD1 as well as LRP in tumor tissues [52]. Similarly, Puerarin was 
TABLE 5: Natural products overcome drug resistance in serum pharmacology studies.

\begin{tabular}{|c|c|c|c|c|c|c|}
\hline Name & Dose (days) & Serum dose $^{1}$ & Cell model & Chemodrug & $\mathrm{IDS}^{2}$ & Reference \\
\hline Buzhong Yiqi Tang & $5.7 \mathrm{~g} / \mathrm{kg}(3)$ & 15 & A549/DDP & Cisplatin & 3 & {$[161]$} \\
\hline Jiedu Huayu recipe & $3 \mathrm{~g} / \mathrm{kg}(3)$ & 10 & HL60/Adr & Doxorubicin & 8.4 & {$[162]$} \\
\hline Scutellariae barbatae & $14.1 \mathrm{~g} / \mathrm{kg}(4)$ & 0.5 & K562/A02 & Various & $2.2-5.4$ & {$[163]$} \\
\hline Shehuang Xiaoliu & $29.7 \mathrm{~g} / \mathrm{kg}(10)$ & 20 & Bel7402 & Doxorubicin & 8.3 & [164] \\
\hline Zedoary turmeric oil & $0.8 \mathrm{mg} / \mathrm{kg}(3)$ & 20 & SGC7901/CDDP & Verapamil & 6.1 & {$[165]$} \\
\hline
\end{tabular}

${ }^{1}$ Percentage of serum being tested in addition to the conventional $10 \%$ of fetal bovine serum in cell culture.

${ }^{2}$ IDS, increase in drug sensitivity ( $x$-fold).

IDS = IC50 in control group/IC50 in experimental group.

found to increase the tumor growth inhibition rate from $18.1 \%$ (treated with 5-fluorouracil, control group) to $56.7 \%$ (treated with 5-fluorouracil plus puerarin, experimental group) and decrease the protein levels of MDR1 and MRP in tumor tissues [53]. In nude mice with tumor xenograft (HCT8/VCR cells), curcumin increases the chemotherapeutic potential of vincristine and decreases the protein levels of MDR1 as well as survivin in the tumor cells [54]. Cepharanthine $(4 \mu \mathrm{M})$ is not toxic to EAC/ADR cells in vitro but can increase the cell sensitivity to doxorubicin by 13 times and inhibit NF- $\kappa \mathrm{B}$ activity which is upregulated in the drug resistant cells. In mice model, the compound can increase the life span of mice by $75.4 \%$. Wang [55] developed a mouse liver cancer cell line (Hca cells) model to investigate antidrug resistance effect of cepharanthine hydrochloride. The resistant cells have higher levels of MDR1 and MRP1 compared to their drug sensitive parental cells and are resistant to multiple chemodrugs such as etoposide, daunorubicin, and vincristine. In mice bearing drug resistant Hca cells, cepharanthine hydrochloride can inhibit the expression of the drug transporters and increase the intracellular concentration of chemodrugs as well as life span of animals. In mice bearing drug resistant S180 sarcoma cells, matrine $(100 \mathrm{mg} / \mathrm{kg}$ a day for 10 days) reduces the protein levels of MDR1, LRP, and Topo II by 78\%, $84 \%$, and $65 \%$, respectively [56]. Also in S180-bearing mice, tetrandrine reduces the protein level of MDR1, increases the protein levels of Fas and Trail, and enhances the tumor cell apoptosis [57]. These results indicate that the natural products are potent agents to overcome cancer cell drug resistance in vivo, by inhibiting molecules that mediate drug resistance.

\section{Clinical Studies}

The ultimate goal of laboratory investigations is to achieve clinical applications. In clinical studies, patients are commonly divided into two groups. Patients in control group receive conventional chemotherapy. Patients in treatment group receive conventional chemotherapy plus natural product(s). Hu and coworkers [58] investigated the effect of Fritillariae thunbergii in 90 acute leukemia patients and found that the patients in the treatment group had lower number of leukemia cells in bone marrow, decreased protein level of MDR1, and decreased remission rate, compared with patients in the control group. Li and coworkers [59] investigated the effect of the Fritillariae thunbergii in 30 patients with acute leukemia patients who expressed high level of MDR1. The patients in the treatment group had lower protein level of MDR1 (3 times lower), higher therapy response rate (20\% versus $55 \%$ ), and lower percentage of leukemic cells in bone marrow (50\% versus 26\%). Zhao and coworker [60] recruited 36 patients with acute leukemia, who were positive to MRP protein. They performed real-time PCR to quantify bone marrow cell mRNA levels of MRP and $\beta 2 \mathrm{M}$, and patients with $\mathrm{MRP} / \beta 2 \mathrm{M}$ value equal to or greater than 0.3 were considered as MRP positive. The patients treated with ligustrazine injection ( $120 \mathrm{mg}$ iv. daily for 15 days) were more likely to turn negative for MRP (45.5 versus $7.1 \%$ ) and have lower percentage of leukemic cells in bone marrow (21.4 versus 55.6\%). Some other clinical studies and benefits are included in Table 6. The compositions of formulas are shown in Table 7.

\section{Conclusion}

Drug resistance explains a big part of failure in cancer chemotherapy. Despite the efforts to overcome cancer cell drug resistance, there is no satisfactory solution so far. Natural products provide a vast pool for screening for drugs including candidate compounds to overcome drug resistance. Although the studies included in this review are not particularly rich in scientific details, they show that many natural products, used alone or in combination, are potent inhibitors of drug resistance under laboratory conditions and in clinical setting, which provides informative original observations (including many first time reports) for the scientific and industrial communities. Some single compounds and herbal ones as well as all of the herbal formulas have already been used clinically in treating various diseases including cancer. Future studies may identify natural products for clinical management of cancer cell drug resistance.

\section{Conflict of Interests}

The authors have no actual or potential conflict of interests regarding the publication of this paper.

\section{Authors' Contribution}

$\mathrm{Pu}$ Wang and Hua Li Yang contributed equally to the review. 
TABLE 6: Clinical studies and benefits.

\begin{tabular}{|c|c|c|c|}
\hline $\begin{array}{l}\text { Disease (number of } \\
\text { patients) }\end{array}$ & Treatment agent & Clinical benefit & Reference \\
\hline $\begin{array}{l}\text { Relapsed non-Hodgkin's } \\
\text { lymphoma (60) }\end{array}$ & Ligustrazine & Higher overall response rate & {$[166]$} \\
\hline Breast cancer $(76)$ & $\begin{array}{l}\text { Chinese } \\
\text { magnolcavine fruit }\end{array}$ & $\begin{array}{l}\text { Increase in response rate, delayed remission, and } \\
\text { increase in the MRP negativity rate }\end{array}$ & [167] \\
\hline $\begin{array}{l}\text { Advanced gastrointestinal } \\
\text { cancer (54) }\end{array}$ & $\begin{array}{l}\text { Changweiqing } \\
\text { formula }\end{array}$ & $\begin{array}{l}\text { Higher response rate and Karnofsky score } \\
\text { Longer survival time } \\
\text { Lower level of MDR1 in blood cells }\end{array}$ & {$[168]$} \\
\hline $\begin{array}{l}\text { Gastric cancer, stages II-III } \\
(30)\end{array}$ & Didang formula & $\begin{array}{l}\text { Higher response rate and better life quality } \\
\text { Lower level of MDR1 in blood cells }\end{array}$ & [169] \\
\hline Liver cancer $(71)$ & Xiaochaihu formula & $\begin{array}{l}\text { Higher response rate and lower protein level of MDR1 } \\
\text { in cancer tissue }\end{array}$ & {$[170]$} \\
\hline $\begin{array}{l}\text { Gastric cancer, stages II-III } \\
(60)\end{array}$ & $\begin{array}{l}\text { Shenqi Jianwei } \\
\text { formula }\end{array}$ & $\begin{array}{l}\text { Higher response rate, lower level of lower of CEA, and } \\
\text { higher Karnofsky score }\end{array}$ & {$[171]$} \\
\hline Breast cancer (60) & Pingxiao formula & $\begin{array}{l}\text { Higher response rate and lower protein levels of MDR1 } \\
\text { and GST } \pi \text { in cancer tissues }\end{array}$ & {$[172]$} \\
\hline Breast cancer (53) & Fukangling capsule & $\begin{array}{l}\text { Higher response rate and lower protein levels of MDR1 } \\
\text { and GST } \pi \text { in cancer tissues }\end{array}$ & {$[173]$} \\
\hline $\begin{array}{l}\text { Non-small cell lung cancer } \\
(60)\end{array}$ & Qiankun capsule & $\begin{array}{l}\text { Lower level of blood TGF- } \alpha \text { and lower number of } \\
\text { PCNA positive cells as well as lower protein levels of } \\
\text { LRP and MRP in cancer tissue }\end{array}$ & {$[174]$} \\
\hline $\begin{array}{l}\text { Breast cancer, stages II-III } \\
(33)\end{array}$ & Fukangling capsule & $\begin{array}{l}\text { Higher response rate and lower protein level of MDR1 } \\
\text { in cancer tissue }\end{array}$ & {$[174]$} \\
\hline
\end{tabular}

TABLE 7: Major composition of formulas.

\begin{tabular}{|c|c|}
\hline Name of formula & Major composition \\
\hline Changweiqing & $\begin{array}{l}\text { Astragalus membranaceus, Atractylodes macrocephala Koidz, Radix Codonopsis Pilosulae, Polyporus, Coix } \\
\text { chinensis Tod, Fructus Akebiae Trifoliatae, Vitis quinquangularis Rehd, and Sargentodoxa cuneata (Oliv.) Rehd. et } \\
\text { Wils }\end{array}$ \\
\hline Wenxia Fang & Rhizoma et Radix Rhei Palmat, Aconitum carmichaeli Debx, Panax ginseng C. A. Mey, and Angelica sinensis \\
\hline Buzhong Yiqi & $\begin{array}{l}\text { Astragalus membranaceus, Radix Glycyrrhizae, Panax ginseng C. A. Mey, Angelica sinensis, Pericarpium Citri } \\
\text { Reticulatae, Cimicifuga foetida L., Radix Bupleuri, and Atractylodes macrocephala Koidz }\end{array}$ \\
\hline Jiedu Huayu & $\begin{array}{l}\text { Indigo Naturalis, Asarum sagittarioides C. F. Liang, Rhizoma Paridis Chinensis, Curcuma zedoaria (Christm.) } \\
\text { Rosc., Rhizoma Chuanxiong, Radix Salviae Miltiorrhizae, and Fructus Psoraleae }\end{array}$ \\
\hline Shehuang Xiaoliu & $\begin{array}{l}\text { Moschus berezovskii Flerov, Bos taurus domesticus Gmelin, Curcuma zedoaria (Christm.) Rosc., Astragalus } \\
\text { membranaceus, Radix Codonopsis Pilosulae, Scutellaria barbata D. Don., and Hedyotis diffusa }\end{array}$ \\
\hline Didang & Hirudo, Tabanus, Semen Persicae, and Rhizoma et Radix Rhei Palmat \\
\hline Xiaochaihu & $\begin{array}{l}\text { Viola philippica Car., Hedyotis diffusa, Pyrrosia lingua (Thunb.) Farwell, Zaojiaoci (Spina Gleditsiae), Manis } \\
\text { pentadactyla Linnaeus, and Smilax glabra Roxb. }\end{array}$ \\
\hline Shenqi Jianwei & $\begin{array}{l}\text { Radix Codonopsis Pilosulae, Astragalus membranaceus, Atractylodes macrocephala Koidz, Angelica sinensis, } \\
\text { Radix Paeoniae Alba, Smilax china L., Taraxacum mongolicum, Crataegus pinnatifida, Perilla frutescens (L.) } \\
\text { Britton., Radix Aristolochiae, and Pericarpium Citri Reticulatae }\end{array}$ \\
\hline Pingxiao & $\begin{array}{l}\text { Curcuma longa L., Agrimonia pilosa Ledeb., Trogopterus xanthipes Milne-Edwards, Alumen, Nitrum, } \\
\text { Toxicodendron vernicifluum (Stokes) F. A. Barkl., Bitter Orange Fructus Aurantii, and Strychnos nux-vomica } \\
\text { Linn. }\end{array}$ \\
\hline Fukangling capsule & $\begin{array}{l}\text { Panax ginseng C. A. Mey, Astragalus membranaceus, Ganodermae Lucidi, Rhizoma Polygonati, Radix Glehniae, } \\
\text { and Fructus Schisandrae Chinensis }\end{array}$ \\
\hline Qiankun capsule & $\begin{array}{l}\text { Radix Codonopsis Pilosulae, Radix Rehmanniae, Astragalus membranaceus, Fructus Psoraleae, Furctus Lycii } \\
\text { barbari, Fructus Ligustri Lucidi, Asarum sagittarioides C. F. Liang, Rhizoma Dioscoreae Bulbiferae, Indigo } \\
\text { Naturalis, Herba Cirsii Setosi, Panax notoginseng, Lobed Kudzuvine Root, and Bos taurus domesticus Gmelin }\end{array}$ \\
\hline Huatan Sanjie & $\begin{array}{l}\text { Smilax china, Rhizoma pinelliae, Bulbus Fritillariae Thunbergii, Coix chinensis Tod, Pollen, and Curcuma } \\
\text { zedoaria (Christm.) Rosc. }\end{array}$ \\
\hline
\end{tabular}




\section{Acknowledgments}

This study is supported by the direct grant from the Shanxi University (no. 0113-113533801005) and International Collaboration grant from the Department of Science and Technology of Shanxi Province to Dr. Shao Chin Lee.

\section{References}

[1] B. Stewart and C. P. Wild, World Cancer Report, IARC Nonserial Publication, 2014.

[2] J. L. Markman, A. Rekechenetskiy, E. Holler, and J. Y. Ljubimova, "Nanomedicine therapeutic approaches to overcome cancer drug resistance," Advanced Drug Delivery Reviews, vol. 65, no. 13-14, pp. 1866-1879, 2013.

[3] D. C. Swinney and J. Anthony, "How were new medicines discovered?” Nature Reviews Drug Discovery, vol. 10, no. 7, pp. 507-519, 2011.

[4] C. Basmadjian, Q. Zhao, E. Bentouhami et al., "Cancer wars: natural products strike back," Frontiers in Chemistry, vol. 2, article 20, 2014.

[5] P. A. Sotiropoulou, M. S. Christodoulou, A. Silvani, C. HeroldMende, and D. Passarella, "Chemical approaches to targeting drug resistance in cancer stem cells," Drug Discovery Today, vol. 19, no. 10, pp. 1547-1562, 2014.

[6] A. Cort and T. Ozben, "Natural product modulators to overcome multidrug resistance in cancer," Nutrition and Cancer, vol. 67, no. 3, pp. 411-423, 2015.

[7] D.-M. Zhang, C. Shu, J.-J. Chen et al., "BBA, a derivative of 23hydroxybetulinic acid, potently reverses $\mathrm{ABCB} 1$-mediated drug resistance in vitro and in vivo," Molecular Pharmaceutics, vol. 9, no. 11, pp. 3147-3159, 2012.

[8] H.-Q. Guo, G.-N. Zhang, Y.-J. Wang et al., " $\beta$-Elemene, a compound derived from Rhizoma zedoariae, reverses multidrug resistance mediated by the $\mathrm{ABCB} 1$ transporter," Oncology Reports, vol. 31, no. 2, pp. 858-866, 2014.

[9] X.-C. Huang, X. Xiao, Y.-K. Zhang et al., "Lamellarin O, a pyrrole alkaloid from an Australian marine sponge, Ianthella sp., reverses BCRP mediated drug resistance in cancer cells," Marine Drugs, vol. 12, no. 7, pp. 3818-3837, 2014.

[10] Y. Zhang, Y. Zhang, Y. Wang et al., "Esters of the marinederived triterpene sipholenol A reverse P-GP-mediated drug resistance," Marine Drugs, vol. 13, no. 4, pp. 2267-2286, 2015.

[11] G. Housman, S. Byler, S. Heerboth et al., "Drug resistance in cancer: an overview," Cancers (Basel), vol. 6, no. 3, pp. 17692792, 2014.

[12] Q. Wu, Z. Yang, Y. Nie, Y. Shi, and D. Fan, "Multi-drug resistance in cancer chemotherapeutics: mechanisms and lab approaches," Cancer Letters, vol. 347, no. 2, pp. 159-166, 2014.

[13] R. K. Vadlapatla, A. D. Vadlapudi, D. Pal, and A. K. Mitra, "Mechanisms of drug resistance in cancer chemotherapy: coordinated role and regulation of efflux transporters and metabolizing enzymes," Current Pharmaceutical Design, vol. 19, no. 40, pp. 7126-7140, 2013.

[14] F. J. Sharom, "ABC multidrug transporters: structure, function and role in chemoresistance," Pharmacogenomics, vol. 9, no. 1, pp. 105-127, 2008.

[15] L. A. Doyle, W. Yang, L. V. Abruzzo et al., "A multidrug resistance transporter from human MCF-7 breast cancer cells," Proceedings of the National Academy of Sciences of the United States of America, vol. 95, no. 26, pp. 15665-15670, 1998.
[16] P. A. Fetsch, A. Abati, T. Litman et al., "Localization of the ABCG2 mitoxantrone resistance-associated protein in normal tissues," Cancer Letters, vol. 235, no. 1, pp. 84-92, 2006.

[17] E. L. Niero, B. Rocha-Sales, C. Lauand et al., "The multiple facets of drug resistance: one history, different approaches," Journal of Experimental \& Clinical Cancer Research, vol. 33, no. 1, article 37, 2014.

[18] I. R. Indran, G. Tufo, S. Pervaiz, and C. Brenner, "Recent advances in apoptosis, mitochondria and drug resistance in cancer cells," Biochimica et Biophysica Acta-Bioenergetics, vol. 1807, no. 6, pp. 735-745, 2011.

[19] D. S. Backos, C. C. Franklin, and P. Reigan, "The role of glutathione in brain tumor drug resistance," Biochemical Pharmacology, vol. 83, no. 8, pp. 1005-1012, 2012.

[20] F. Joncourt, K. Buser, H. Altermatt, M. Bacchi, A. Oberli, and T. Cerny, "Multiple drug resistance parameter expression in ovarian cancer," Gynecologic Oncology, vol. 70, no. 2, pp. 176$182,1998$.

[21] J. A. Green, L. J. Robertson, and A. H. Clark, "Glutathione S-transferase expression in benign and malignant ovarian tumours," British Journal of Cancer, vol. 68, no. 2, pp. 235-239, 1993.

[22] B. V. Jardim, M. G. Moschetta, C. Leonel et al., "Glutathione and glutathione peroxidase expression in breast cancer: an immunohistochemical and molecular study," Oncology Reports, vol. 30, no. 3, pp. 1119-1128, 2013.

[23] P. Yu, Y. Du, X. Cheng, Q. Yu, L. Huang, and R. Dong, "Expression of multidrug resistance-associated proteins and their relation to postoperative individualized chemotherapy in gastric cancer," World Journal of Surgical Oncology, vol. 12, article 307, 2014

[24] J. Ge, A.-X. Tian, Q.-S. Wang et al., "The GSTP1 105Val allele increases breast cancer risk and aggressiveness but enhances response to cyclophosphamide chemotherapy in North China," PLoS ONE, vol. 8, no. 6, Article ID e67589, 2013.

[25] E. J. Kap, S. Richter, A. Rudolph et al., "Genetic variants in the glutathione S-transferase genes and survival in colorectal cancer patients after chemotherapy and differences according to treatment with oxaliplatin," Pharmacogenetics and Genomics, vol. 24, no. 7, pp. 340-347, 2014.

[26] X. H. Wang, S. J. Zhang, X. Guo, M. L. Sun, Q. P. Li, and H. Y. Liu, "Reversal effect and mechanism of osthole on the multidrugresistance of human bladder cancer cells T24/ADM," China Modern Medicine, vol. 19, pp. 7-9, 2012.

[27] L. Nong, G. Wu, X. F. Dai et al., "Mechanism of reversing MDR of human lung adenocarcinoma cell line A549/DDP by evodiamine," Chinese Clinical Oncology, vol. 15, pp. 487-492, 2010.

[28] J. Hu, Y. Zhang, B. G. Ma, Y. P. Ju, Y. L. Li, and W. Cheng, “The experimental studies of celastrol on the reversal of multidrug resistance in K562/A02 cell line," The Practical Journal of Cancer, vol. 26, pp. 226-229, 2011.

[29] R. Hu, K. Zhu, X. Y. Zhang et al., "Embelin overcome the resistance of K562/D to daunorubicin," Journal China Medical Univrsity, vol. 39, pp. 272-275, 2010.

[30] H. W. Yang, C. X. Qu, H. W. Guan, and H. W. Yang, "Arsenic trioxide reversing the multidrug resistance of gastric carcinoma cell line SGC7901/ADR to adriamycin," Cancer Research on Prevention and Treatment, vol. 33, pp. 148-149, 2006.

[31] M. Liang, Y. Q. Zhou, S. J. Xiao, and Z. K. Dai, "Netferine reverses drug resistance of human ovarian cancer SKOV3/DDP cells," Shandong Medical Journal, vol. 51, pp. 39-41, 2011. 
[32] W. G. Wang, G. Q. Yu, G. Y. Zhang, C. Zhang, and H. Dong, "Quercetin overcomes drug resistance of K562/ADM cells," Heilongjiang Medicine and Pharmacy, vol. 34, pp. 28-29, 2011.

[33] Y.-Y. Chen, J. Li, J.-D. Hu et al., "Reversing effects of emodin on multidrug resistance in resistant HL-60/ADR cells," Journal of Experimental Hematology, vol. 21, no. 6, pp. 1413-1422, 2013.

[34] L. Liang, S. Y. Liu, J. Wang, and W. Jiang, "Irisquinone overcomes drug resistance of A549/DDP cells," National Medical Journal of China, vol. 81, pp. 1392-1393, 2001.

[35] M. H. Liu, M. P. Ren, R. Li, Z. Zhang, and S. H. Xiao, "Reversal effect of tetramethylpyrazine on cisplatin-resistant ovarian cancer cell line COC1/DDP," Chongqing Medicine, vol. 40, pp. 1982-1987, 2011.

[36] H.-G. Qu, L. Gao, D. He et al., "Effect of reversion of ganoderma lucidum polysaccharides on cisplatin resistant in ovarian cancer cells and its mechanism," Journal of Jilin University Medicine Edition, vol. 37, no. 2, pp. 250-254, 2011.

[37] L. G. Lu, M. D. Zeng, Y. M. Mao et al., "Oxymatrine in the treatment of chronic hepatitis B for one year: a multicenter random double-blind placebo-controlled trial," Zhonghua Gan Zang Bing Za Zhi, vol. 12, no. 10, pp. 597-600, 2004.

[38] B.-S. Shen and X.-W. Song, "Effects of oxymatrine on serum cytokines and hepatic fibrotic indexes in patients with chronic hepatitis B," Zhongguo Zhong Xi Yi Jie He Za Zhi, vol. 28, no. 1, pp. 17-19, 2008.

[39] K. Liang, W. Wei, and Y. Y. Guan, "Clinical application prospects of berberine," Medical Recapitulate, vol. 18, pp. 2842-2843, 2012.

[40] M. L. Duan and J. Song, "Pharmacology of ephedrine," in Proceedings of the Symposium of Chinese Annual Meeting of Anesthesia, 2008.

[41] C. Fan, "The observation of the effects of disodium norcantharidate in the treatment of advanced primary liver cancer," Journal of Basic and Clinical Oncology, vol. 23, pp. 50-51, 2010.

[42] Y. L. Wang, X. L. Bi, J. Gu, and S. Q. Gao, "Study on the mechanism of baicalin in psoriasis treatment," Chinese Journal of Dermatovenerology of Integrated Traditional and Western Medicine, vol. 2, pp. 209-211, 2003.

[43] I. Hiroko, A. Sakae, and O. Yukio, "Effect of shosaikoto, a japanese and chinese traditional herbal medicinal mixture, on the mitogenic activity of lipopolysaccharide: a new pharmacological testing method," Journal of Ethnopharmacology, vol. 21, no. 1, pp. 45-53, 1987.

[44] W. L. Deng, J. H. Xu, C. L. Li, Y. Sun, Y. Zhang, and Z. Z. Fan, "Reversal of multidrug resistance by Changweiqing on vincristine-resistant human colorectal cancer cell line HCT8/V," Tumor, vol. 28, pp. 755-757, 2008.

[45] J. H. Xu, Z. Z. Fan, J. Sun et al., "Reversal of mulitdrug resistance by Changweiqing oral liquid on human oral epidermoid carcinoma cell line KB-A-1,” Tumor, vol. 25, pp. 562-565, 2005.

[46] X. M. Ji, B. Ouyang, C. Y. Wang, Y. Q. Zhang, and T. Jiang, "Wenxiafang, a traditional Chinese college of basic medical sciences, chemotherapeutic resistance in A549/DDP cells by down-regulating expression levels of P-gp, LRP and MRP," China Remedies \& Clinics, vol. 6, pp. 885-888, 2006.

[47] J. Liu, "Treatment of constipation using Changweiqing," Shanxi Journal of Traditional Chinese Medicine, vol. 29, pp. 11-12, 2013.

[48] Q. Cao, Y. Sun, J. F. Shen, and Z. Z. Fan, "Clinical use of Changweiqing to control the infection of Helicobacter pylori," Chinese Journal of Digestion, vol. 20, p. 21, 2000.

[49] Y. X. He, "Clinical treatment of chronic gastritis using changweiqing," Health Must-Read, vol. 12, p. 248, 2013.
[50] Y. Zhang, H. Lu, X. W. Sun, Z. Z. Fan, J. Sun, and J. H. $\mathrm{Xu}$, "Effects of Changweiqing in reversing oxaliplatin resistant HCT116/L-OHP and influence on Pt-DNA adduct," Chinese Traditional Patent Medicine, vol. 34, pp. 1843-1848, 2012.

[51] F. B. Feng, J. Zhuang, H. E. Han, Q. L. Lv, and C. G. Sun, "Research on Chinese herbal compound of reducing phlegm and resolving masses on reversal of multidrug resistance mechanism of MCF-7/ADM transplantation tumor in nude mice," Acta Academiae Medicinae Weifang, vol. 36, pp. 211-213, 2014.

[52] G. Liang, X. Z. Lin, L. Li, M. Zhou, and A. Z. Tang, "MDRreversing effect of (-)epigallocatechin-3-gallate on human MDR cell lines KBV200," Cancer Research on Prevention and Treatment, vol. 34, pp. 4-7, 2007.

[53] L. Wang, P. K. Wei, Z. F. Qin et al., "Experimental study on puerarin injection reverse multidrug resistance of nude mice of human gastric carcinoma constructed using orthotopic transplantation," Journal of Chengdu University of Traditional Chinese Medicine, vol. 28, pp. 42-46, 2005.

[54] W. D. Lu, Z. X. Fu, Y. Qin, L. Li, and C. Yang, "Curcumin reverses multidrug resistance in HCT-8/VCR nude mice xenograft," Acta Academiae Medicinae Militaris Tertiae, vol. 33, pp. 376-380, 2011.

[55] X. Wang, Establishment of Hca multidrug resistance mouse model and study of cepharanthine hydrochloride on overcoming its drug resistance [M.S. thesis], Zhenzhou University, 2008.

[56] F. Sun, N. Wang, G. Li, X. Wang, X. Li, and G. Yin, “The effect of matrine on the expression of P170 LRP and TOPO II of obtained multi-drug resistance of mouse S180's tumour cell," Journal of Chinese Medicinal Materials, vol. 27, no. 11, pp. 838-840, 2004.

[57] F.-J. Sun, X.-C. Nie, G.-H. Li, and G.-P. Yin, "The study of tetrandrine on reversion of P170 and apoptosis of obtained multi-drug resistante of mice S180's tumour cell," China Journal of Chinese Materia Medica, vol. 30, no. 4, pp. 280-283, 2005.

[58] K. W. Hu, X. Y. Chen, M. H. Zuo et al., "Fritillaria thunbergii powder overcomes drug resistance of acute leukemia patients," China Journal of Traditional Chinese Medicine and Pharmacy, vol. 19, pp. 68-70, 2004.

[59] W. Li, K. W. Hu, W. Su, Y. L. Sun, X. Y. Chen, and B. Liang, "Clinical trial of Fritillaria thunbergii Bulb powder for reversing multidrug resistance in the patients with acute leukemia," Journal of Beijing University of Traditional Chinese Medicine, vol. 27, pp. 63-65, 2004.

[60] Y. C. Zhao, X. Y. Chen, Y. M. Xu, and Z. Jia, "Principal clinical study on ligustrazine injection to counteract the multi-drug resistance of acute leukemia," Chinese Journal of Information on Traditional Chinese Medicine, vol. 10, pp. 10-11, 2003.

[61] L. Q. Zhu, S. Xu, L. Luo, Z. Li, L. L. Qiu, and C. F. Xu, "Reversal of multidrug resistance in drug-resistance human choriocarcinoma cell line JAR/VP16 by effective component of Verbena officinalis L.," Acta Universitatis Medicinalis Nanjing, vol. 27, pp. 419-423, 2007.

[62] J. H. Li, G. Q. Qin, and P. M. Yang, "Reversal of multidrug resistance in human K562/ADM cell line by dauricine," Journal of Dalian Medical University, vol. 24, pp. 94-96, 2002.

[63] W. Q. Chen, H. W. Qi, C. G. Wu, Z. K. Li, C. W. Bai, and Y. G. Liu, "Inhibition of growth on the human lung adenocarcinoma cell line A549 and A549/CDDP in vitro by dihydroartemisinin in combination with cisplatin," Journal of Modern Oncology, vol. 14, pp. 284-286, 2006.

[64] H. Zhang, H.-Q. Wang, H.-L. Zhang, D. Kong, and X.-Z. Wu, "Ginsenoside Rh2 reverses p-glycoprotein-mediated multidrug 
resistance of MCF-7/ADM cells," Tumor, vol. 27, no. 5, pp. 365369, 2007.

[65] Y. L. Zhou, Z. W. Zhou, and R. Zeng, "Reversal effect of isorhynchophylline on cisplatin resistance of line A549/DDP human lung adenocarcinoma cells," Central South Pharmacy, vol. 6, pp. 267-269, 2008.

[66] Y. L. Zhou, M. X. Tang, and S. K. Liu, "Reversal effect of isorhynchophylline on lung adenocarcinoma drug-resistant cell line A549/DDP," Chinese Journal of New Drugs, vol. 18, p. 1338, 2009.

[67] Z. W. Zhou and Y. L. Zhou, "Effect of isorhynchophylline liposomes on cisplatin resistance of human lung adenocarcinoma cell line A549/DDP," Journal of Traditional Chinese Medicine University of Hunan, vol. 28, pp. 29-31, 2008.

[68] J. H. Li and P. M. Yang, "Study on ligustrazine in reversing multidrug resistance of K562/ADM cell," Modern Journal of Integrated Traditional Chinese and Western Medicine, vol. 10, pp. 1405-1407, 2001.

[69] Q. Fan, G. J. Fan, J. Y. Zhao, and P. M. Yang, "Study on effect reversing MDR of ligustrazine liposomes on human erythroleukemia-cell-line K562/ADM," China Pharmacist, vol. 7, pp. 753-755, 2004.

[70] Y. F. Ding, X. Xie, J. Y. Zhao, and P. M. Yang, "Reversal of adriamycin resistance by matrine in leukemia multidrug resistance cell line K562/ADM," Journal of Dalian Medical University, vol. 26, pp. 256-259, 2004.

[71] P. Zhang, Z. Y. Gu, Y. H. Sun, and Y. Z. Nie, "Reversal effect of peiminine on gastric cancer multidrug resistance," Journal of Xinjiang Medical University, vol. 35, pp. 452-456, 2012.

[72] L. Li and Q. X. Fan, "Reversal effect of schisandrin A on MRP1mediated multidrug resistance," Journal of Chinese Practical Diagnosis and Therapy, vol. 23, pp. 857-859, 2009.

[73] D. Pang, Study of the reversal effect of tanshinone II. A on multidrug-resistance of breast cancer [M.S. thesis], Sichuan University, 2007.

[74] Y. Q. Shi, M. Deng, L. X. Zhu, and R. X. Yu, "Primary study on reversal effect of radix acanthoparacis senticosi on multidrug resistance of K562/ADR cells in vitro," Chinese Journal of Traditional Medical Science and Technology, vol. 11, pp. 93-95, 2004.

[75] Y. Han, L. M. Bu, X. Ji, C. Y. Liu, and Z. H. Wang, "Modulation of multidrug resistance by andrographolid in a HCT-8/5-FU multidrug-resistant colorectal cancer cell line," Chinese Journal of Digestive Diseases, vol. 6, no. 2, pp. 82-86, 2005.

[76] B. Jiang and Q. L. Liu, "The reverse role of the activity of Banlangen to human multidrug-resistant hepatocarxinoma cell," Journal of Jining Medical College, vol. 27, pp. 11-13, 2004.

[77] H. Liu, "Reversal effect of Angelicae sinensis on DOX resistance gastric cancer cell line SGC-7901/ADR," World Health Digest, vol. 6, pp. 31-33, 2009.

[78] B. Liao, R. Y. Ge, C. B. Xu et al., "Reversal effect of Chinese medicine compound FFJZ on multidrug resistance of leukemia K562/VCR cell line," Journal of Fujian University of Traditional Chinese Medicine, vol. 21, pp. 9-12, 2011.

[79] H. J. Xing, H. Y. Cui, and J. H. Zhao, "Apigenin reverses drug resistance of HCT8/5-FU cells by down-regulation of MDR1," Chinese Journal Gerontology, vol. 34, pp. 3709-3712, 2014.

[80] J. Cheng, J. P. Feng, Y. P. Wang, M. Li, and Q. Z. Kong, "Effect of arsenic trioxide on MRP expression in A549/R cell line of human lung cancer," Herald of Medicine, vol. 26, pp. 457-460, 2007.
[81] H. Li, M.-M. Xiong, X.-L. Meng, and X.-P. Geng, "Reversing effect of arsenic trioxide on multidrug resistance of human hepatocellular carcinoma HepG2/ADM cells," World Chinese Journal of Digestology, vol. 14, no. 27, pp. 2691-2694, 2006.

[82] H. W. Yang, C. X. Qu, and H. W. Guan, "Arsenic trioxide reversing the multidrug resistance of gastric carcinoma cell line SGC7901/ADR to adriamycin," Cancer Research on Prevention and Treatment, vol. 33, pp. 148-149, 2006.

[83] H. P. Yu, L. Cui, and Y. J. Pan, "Reversal of drug resistance in multidrug-resistant MCF-7/ADR cells of breast cancer by artemisinin," Acta Medicinae Universitatis Scientiae et Technologiae Huazhong, vol. 40, pp. 91-94, 2011.

[84] X. J. Fu, H. Yao, L. E. Lin et al., "Study on artesunate in reversing MDR of multiple myeloma cell lines," Acta Universitatis Medicinalis Anhui, vol. 48, pp. 1075-1078, 2013.

[85] L. J. Yang, T. Zhao, Q. X. Bai, and H. J. Dong, "Reversal effect and machenism induced by baicalin on leukemia cell line," Shanxi Medical Journal, vol. 41, pp. 775-779, 2012.

[86] S. H. Wang, "The multidrug-resistant mechanism study of reverse effect of Baicalin for hepatocellular carcinoma cell line (Bel 7402/ADM)," Chinese Journal of Modern Drug Application, vol. 6, pp. 10-11, 2012.

[87] Y. Q. Han, Y. J. Shi, J. Y. Yuan, Y. Zhu, and S. L. Wu, “The study of reversal resistance effect and its mechanism of berbamine in MCF7/ADR cells," Acta Anatomica Sinica, vol. 35, pp. 161-164, 2004.

[88] Y. Wu, Y. Zeng, and S. Y. Liang, “The exploratory research on the berberine reverse the HCT-8/VCR multidrug resistance and its relationship with P-gp functional variance," Guide of China Medicine, vol. 8, pp. 18-20, 2010.

[89] X. L. Yu, H. Li, X. L. Chen, X. X. Li, R. Wang, and F. Gao, "Study on reversing mechanism of multidrug resistance of K562/A02 cell line by carnosic acid," Chinese Journal of Hematology, vol. 31, pp. 381-384, 2010.

[90] Z. Cao, L.-J. Wang, M.-H. Wu, Y. Qiao, Y.-J. Sun, and J. Guo, "Mechanism governing reversal of multidrug resistance in human breast carcinoma cells by chelerythrine," Acta Academiae Medicinae Sinicae, vol. 33, no. 1, pp. 45-50, 2011.

[91] Y. Qin, Z. X. Fu, W. D. Lu, L. Li, and W. X. Tang, "Experimental study of multidrug-resistance reversing of curcumin on human colon carcinoma HCT-8/VCR cells," Chinese Journal of Biochemical Pharmaceutics, vol. 32, pp. 173-179, 2011.

[92] H. Y. Chang, F. C. Oan, X. Y. Jiao et al., “The study on reversing mechanism of multidrug resistance of K562/A02 cell line by curcumin and erythromycin," Chinese Journal of Hematology, vol. 27, pp. 254-257, 2006.

[93] L. Wang, P. K. Wei, Z. F. Qin et al., "Experimental study on reversion effect of elemene on multidrug resistance of human gastric cancer cell line," Journal of Chengdu University of Traditional Chinese Medicine, vol. 28, pp. 51-53, 2005.

[94] C. M. Chen, W. Z. Yang, C. H. Wang, X. Y. Yang, and S. S. Shi, "Reverse of drug resistance against ADM in U251/ADM cells by elemene," Chinese Journal of Experimental Surgery, vol. 23, pp. 601-603, 2006.

[95] C. C. Yao, Y. R. Tu, J. Jiang et al., "Elemene reversed the multidurg resistance of A549/DDP lung cancer cells via mitochondrial apoptosis pathway," Journal of Modern Oncology, vol. 22, pp. 1276-1281, 2014.

[96] J. Q. Mao, Y. Zhang, J. Gu, X. Zhang, and L. Ma, "Reversal of multidrug resistance in K562/A02 cell by ephedrine," Chinese Journal of Hospital Pharmacy, vol. 27, pp. 156-159, 2007. 
[97] F. Zhao, M. H. Zhang, X. L. Chen et al., "MDR-reversing effect of EGCG by decreasing expression of p-glycoprotein on human leukemic cell line," Journal of Oncology, vol. 10, pp. 389-392, 2004.

[98] Y. H. Li, "Experimental study on EGCG reversing the multidrug resistance of esophageal cancer cell line Eca109/DDP," Guide of Chinese Medicine, vol. 11, pp. 414-415, 2013.

[99] P. Yang, J. Cao, M. H. Tan et al., "Reversal of resistance to Oxaliplatin in human colon cancer by gambogic acid," Chinese Archives of General Surgery (Electronic Edition), vol. 7, pp. 273277, 2013.

[100] Y. Li, Z. Z. Wang, and T. F. Yu, "In vitro study on the reversal of multidrug resistance (MDR) in HL60/VCR cell line with ginsenoside-Rb1, Journal of Radioimmunology, vol. 18, pp. 362365, 2005.

[101] H. L. Wen, X. M. Li, W. T. Zeng, and K. L. Zhu, "Effect of ginsenoside on reversal of multidrug resistance of hepatocellular carcinoma cells bel-7402: an experimental study," Chinese Journal of Biomedical Engineering, vol. 18, pp. 191-194, 2012.

[102] W. Zhang, S. Y. Liu, J. Wang et al., "Reversal effect of ginsenoside $\mathrm{Rg} 3$ on cisplatin-resistant human lung adenocarcinoma cell line (A549DDP) and its mechanisms," Chinese Journal of Respiratory and Critical Care Medicine, vol. 1, pp. 100-103, 2002.

[103] L. Dong, X. Q. Tang, J. G. Cao, S. H. Shi, Y. Z. Zhuang, and J. G. Zhou, "Reversal effect of neferine on resistance to vincristine in human multidrug-resistant gastric carcinoma cell line SGC7901/VCR," Chinese Journal of Pathophysiology, vol. 20, pp. 1407-1410, 2004.

[104] X.-B. Xiao, Z.-X. Xie, J. Chen, Q. Qin, and Y. Zhu, "Effect of neferine on the chemotherapic sensitivity of STI 571 to K562/A02 cells," Journal of Central South University (Medical Sciences), vol. 30, no. 5, pp. 558-561, 2005.

[105] C. H. Huang and P. G. Cai, "The study of neferine on multidrug resistance reversing of the human breast cancer cell line MCF7/Adr," Cancer Research on Prevention and Treatment, vol. 34, pp. 351-353, 2007.

[106] J. J. Guo, X. L. Pan, C. W. Feng, and J. H. Zhou, "Study on reversal effects of Oridonin on multidrug resistant cell line K562/A02," Shanghai Medical Journal, vol. 25, pp. 43-45, 2002.

[107] J. Y. Lv and Y. Zhao, "Oxymatrine overcomes the drug resistance of MCF-7/ADM cells," China Modern Doctor, vol. 48, pp. 86-87, 2010.

[108] X. Y. Tang and Y. X. Tang, "Efficiency and mechanisms of peimine reversing multi-drug resistance of A549/DDP cell line," Shandong Medical Journal, vol. 52, pp. 4-6, 2012.

[109] Y. Cai, T. G. Cai, F. D. Tang, R. H. Zhang, L. He, and L. Q. Xu, "Reversal effect of multidrug resistance on K562/ADM cell by Psoralen," Chinese Journal of Clinical Oncology, vol. 31, pp. 146148, 2004.

[110] F. B. Du, M. H. Bao, and X. D. Mei, "Research on the reversal of multidrug resistance of human carcinoma cell line KB-MRP by quercetin," Chinese Clinical Oncology, vol. 12, pp. 659-662, 2007.

[111] X. H. Qiao, H. F. Tang, L. Song, S. Y. Long, D. X. Zhou, and S. C. Liu, "Quercetin reverses drug resistance of leukemia cells," Chinese Journal of Clinical Pharmacology and Therapeutics, vol. 8, pp. 302-303, 2003.

[112] S. X. Chen, Y. Y. Jiang, and Z. H. Fei, "Reversal effect of sodium norcantharidate on human lung adenocarcinoma cell line A549/DDP in vitro," Chinese Journal of Geriatrics, vol. 29, pp. $486-488,2010$.
[113] X. L. Zhao and G. C. Xu, "A study of the reverse effect of tetramethylpyrazine on the resistant cell strain A2780/ADM of human ovarian carcinoma," The Journal of Medical Research, vol. 38, pp. 78-81, 2009.

[114] J. L. Liu, J. Jiang, M. Y. Zhang, Y. Wang, Y. R. Liu, and Y. Wang, "Studies of TMP on restraining proliferation and reversing multidrug resistance in human lung adenocarcinoma cell line," Practical Oncology Journal, vol. 27, pp. 303-307, 2013.

[115] H.-Y. Ma, J.-Y. Zhao, W. Jin, and L. Kong, "Effect of tetramethylpyrazine on reversing multidrug resistance of K562/MDR cells with gene transfer," Journal of Jilin University (Medicine Edition), vol. 35, no. 4, pp. 599-603, 2009.

[116] Y. Sun, K. Q. He, and M. J. Gong, "Reversal effect of tetredrine (TTD) on human hepatocellular carcinoma (HCC) multidrugresistant cell line (Hep-3B/ADM)," China Medicine, vol. 3, pp. 790-791, 2008.

[117] L. F. Yu, Y. L. Wu, and Y. P. Zhang, "Reversal of drug resistance in the vincristine-resistant human gastric cancer cell lines MKN28/VCR by emulsion of seminal oil of Brucea javanica," World Chinese Journal of Digestology, vol. 9, no. 4, pp. 376-378, 2001.

[118] C. L. Ji, Y. Y. Xie, and D. X. Sun, "Jave Brucea fruit extract overcomes drug resistance of K562/ADM cells," Zhejiang Journal of Traditional Chinese Medicine, vol. 45, pp. 458-459, 2010.

[119] C. Zhang, D. M. Wan, and W. J. Cao, "Reversal effect of cinobufacini on multidrug resistance of Raji/ADR cells and its mechanisms," Journal of Experimental Hematology, vol. 22, pp. 1306-1310, 2014.

[120] G. Y. Zhou, L. Li, F. Yu, Y. L. Sun, and C. Ma, "Reversal of grape seed polyphenol on multidrug resistance of MCF 7/ADR in vitro and in vivo," Journal of Shandong University (Health Sciences), vol. 42, pp. 640-642, 2004.

[121] F. F. Yang, Z. M. Wang, and X. L. Wu, "Study on reversal of mutidrug resistance of GBC-SD cell lines by grape seed polyphenols," Chinese Journal of General Surgery, vol. 15, pp. 202-205, 2006.

[122] L. P. Wang, B. Z. Wang, H. Y. Si, C. Zhao, and Z. X. Sui, "Effects of hyaluronate oligomers on drug resistant reverse and apoptosis enhancement in MCF-7/ADM cell line," Bulletin of Chinese Cancer, vol. 15, pp. 617-619, 2006.

[123] R. Li, S. Xie, L. Zhang, and X. M. Wang, "Primary study on the mechanism of reversal drug-resistance of human breast cancer cell line MCF-7 by Huaier Granule," China Practical Medical, vol. 4, pp. 1-2, 2009.

[124] Z. Yu, T. Wu, and Y. Zhang, "The reversal effects of trametes robiniophila murr. on multidrug resistance in resistant human hepatocellular carcinoma cell line BEL-7402/5-Fu," Journal of Chinese Oncology, vol. 19, pp. 443-447, 2013.

[125] N. Liu, X. P. Gen, L. X. Zhu et al., "MDR-reversing effect of extractum Trametes robiniophila Murr on human hepatocellular carcinoma HepG2/ADM in vitro," Chinese Journal of Hepatobiliary Surgery, vol. 13, pp. 385-388, 2007.

[126] Y. Q. Shi and T. D. Tian, "Panax notoginseng extract ovrxomes drug resistance of K562/VCR cells," Chinese Journal of Traditional Medical Science and Technology, vol. 12, pp. 292-294, 2005.

[127] L. L. Liu, Y. E. Liu, and G. T. Fang, "Reversal effect of panaxnotoginseng saponins on multidrug resistance breast cancer cell MCF/ADM," Lishizhen Medicine and Materia Medica Research, vol. 19, pp. 954-956, 2008.

[128] X. Q. Peng, W. Feng, and W. H. Zhang, "Reversal of multirug resistance in K562/A02 cell by alcoholic extract of pinellia 
ternate," Chinese Journal of Experimental Traditional Medical Formulae, vol. 18, pp. 157-160, 2012.

[129] Y. H. Wang, J. Y. Zhao, C. H. Ge, and P. M. Yang, "Reversal effect and mechanism of realgar on multidrug resistance in breast tumor cells MCF-7/ADM," Progress of Anatomical Sciences, vol. 9, pp. 135-138, 2003.

[130] Q. M. Li, B. E. Dan, and J. Zhang, "Reversing effect of thallus laminariae $\mathrm{PE}$ on drug resistance in $\mathrm{B}-\mathrm{MD}-\mathrm{C1}(\mathrm{ADR}+/+)$ Cell Line," Carcinogenesis, Teratogenesis \& Mutagenesis, vol. 19, pp. 219-222, 2007.

[131] C. M. Yang, X. B. Cui, Q. Luo, L. Sun, H. Liu, and L. X. Zhang, "Curcumin reverses cancer cell drug resistance is mediated by caspase-3," The Journal of Practical Medicine, vol. 28, pp. 355$357,2012$.

[132] Y. X. Chi, Artesunate reversing drug resistance and weakening anti-apoptosis mediated Bcl-2 in gastric cancer cells SGC7901/mdr1 [M.S. thesis], Xinxiang Medical University, Xinxiang, China, 2014.

[133] C. C. Yao, Y. R. Tu, H. X. Du et al., "The effect of elemene on reversal multidurg resistance and the expression of $\mathrm{P}$ glycoprotein in A549/DDP,' Journal of Modern Oncology, vol. 21, pp. 2670-2673, 2013.

[134] H. L. Ma, X. J. Zhou, X. Z. Zhang, and T. Wang, "Study of $\beta$ elemene on induction of apoptosis and reverses on tamoxifen drug-resist-ance in human breast cancer cells LCC-2," Journal of Modern Oncology, vol. 22, pp. 2024-2028, 2014.

[135] J. Hu, W. Jin, and P.-M. Yang, "Reversal of resistance to adriamycin in human breast cancer cell line MCF-7/ADM by $\beta$-elemene," Chinese Journal of Oncology, vol. 26, no. 5, pp. 268270, 2004.

[136] X. N. Ouyang, W. Z. Fang, D. S. Wu, S. Q. Lin, J. Chen, and Z. Y. Yu, "The mechanism of rheum emodin reversed resistance of EGFR-TKI in NSCLC," Chinese Clinical Oncology, vol. 19, pp. 967-971, 2014.

[137] F. Zhao, M. H. Zhang, L. Z. Li, C. L. Zhao, and L. Q. Wang, "Research on reversal effect of multidrug resistance in human leukemic cell line by EGCG and its mechanisms," Journal of Clinical Hematology, vol. 18, pp. 33-36, 2005.

[138] S. Hu, Research on the efficiency and mechanisms of gensenoside Rh2 reversing the resistance of lung adenocarcinoma cells to cisplatin [Ph.D. thesis], Zhongnan University, Wuhan, China, 2004.

[139] S. H. Shi and H. Zhang, "Reversal of multidrug resistance by neferine in human gastric carcinoma cell line SGC7901/VCR and its mechanism," The Practical Journal of Cancer, vol. 27, pp. 334-336, 2012.

[140] Y. Liu, K. T. Yao, and G. H. Xiao, "Establishment of the gefitinibresistant A549/GR cell line of human lung adenocarcinoma and investigation of the mechanism of parthenolide in reversing drug resistance," Chongqing Medical Journal, vol. 41, pp. 36893694, 2012.

[141] Q. Ma, F.-X. Zhang, Z.-C. Lv, J.-Y. Chen, and S.-Z. Kang, "Phenylpropanoid glycoside reverse multidrug resistance of colon carcinoma LoVo/Adr cells through induction of apoptosis," World Chinese Journal of Digestology, vol. 17, no. 23, pp. 2357-2361, 2009.

[142] G. M. Sun, X. H. Li, and B. Z. Wang, "Retinoid acid overcomes drug resistance of MCH7/TAM," Shandong Medical Journal, vol. 50, pp. 107-108, 2010.

[143] Y. Q. Huang, Research on reversal of anti-apoptotic action by tetrandrine on adriamycin-resistant human bladder carcinoma cell line BIU-87/ADM and its possible mechanisms [M.S. thesis], Fujian Medical University, 2011.

[144] J. Hu, J.-Y. Zhao, and P.-M. Yang, "Studies of realgar on induction of apoptosis and reversal of drug resistance in human breast tumor cells MCF-7/ADM," Acta Anatomica Sinica, vol. 37, no. 6, pp. 665-668, 2006.

[145] Y.-Q. Han, J.-Y. Yuan, Y.-J. Shi, Y. Zhu, and S.-L. Wu, "Reversal effect of berbamine on multidrug resistance of K562/A02 cells and its mechanism," Journal of Experimental Hematology, vol. 11, no. 6, pp. 604-608, 2003.

[146] X. K. Yu, X. L. Chen, and M. Hou, "Carnosic acid overcomes drug resistance of K562/A02 cells," Chinese Journal of Practical Internal Medicine, vol. 27, supplement 1, p. 66, 2007.

[147] S. Jin, S. E. Chen, M. Zhang et al., "Reversion of MDR of HL60/ADR and MCF-7/ADR with curcumin in vitro," Chongqing Medical Journal, vol. 39, pp. 21-23, 2010.

[148] Y. Y. Chen, J. Li, J. D. Hu et al., "Reversing effects of emodin on multidrug resistance in resistant HL-60/ADR cells," Journal of Experimental Hematology, vol. 2, pp. 1413-1422, 2013.

[149] F. Xue, Z.-Y. Cheng, W.-T. Liang et al., "Resistance reverse effects of honokiol on multidrug resistance of U937/ADR cell line," Journal of Shanghai Jiaotong University, vol. 29, no. 9, pp. 10351039, 2009.

[150] S. Xu, L. Luo, L.-Q. Zhu et al., "Reversal effect of 4 ' -methyletherscutellarein on multidrug resistance of human choriocarcinoma JAR/VP16 cell line," Progress in Biochemistry and Biophysics, vol. 33, no. 11, pp. 1061-1073, 2006.

[151] Y. B. Wang, Z. T. Lu, Q. G. Zhang, X. J. Gao, L. G. Zhang, and H. J. Liu, "Effect of quercetin on multidrug resistance reversal of lung adenocarcinoma cell line A549/DDP," Journal of Binzhou Medical University, vol. 36, pp. 86-89, 2013.

[152] Y.-Q. Han, L.-J. Cao, H.-J. Hao, and Y.-J. Shi, "Effects of quercetin on multidrug resistance and expression of related genes in human erythroleukemic K562/a cells," Journal of Experimental Hematology, vol. 19, no. 4, pp. 884-889, 2011.

[153] Y. Wei, H. Y. Zhang, and G. Liang, "The reverse effect of quercetin on multidrug resistance of human hepatocellular carcinoma," Tianjing Medical Journal, vol. 40, pp. 1022-1025, 2012.

[154] Q. P. Li and Y. N. Gai, "Schisandrin B reverses multidrug resistance due to MDR1-mediated human osteosarcoma cell line U-2 OS/ADR," Anhui Medical and Pharmaceutical Journal, vol. 18, pp. 1642-1645, 2014.

[155] X. Q. Qin, Y. G. Liang, H. Z. Gao et al., "Reversing mechanism of schizandrin A on multi-drug resistance of K562/ADR, HL60/ADR, MCF-7/ADR cell lines," Chinese Pharmacological Bulletin, vol. 27, pp. 329-333, 2011.

[156] J. Cui, J. Ding, Y.-P. Wu, F.-Q. Liu, X.-C. Liu, and Y. Wang, "Reversal effect of sodium selenite on multidrug resistance in K562/ADR cell line and its mechanisms," Journal of Experimental Hematology, vol. 15, no. 4, pp. 756-761, 2007.

[157] Y. S. Li, J. Y. Liu, and Y. Q. Huang, "Reversing mechanism of multidrug resistance of human bladder carcinoma drugresistant cell line BIU-87/ADM by tetrandrine," Chinese Journal of Experimental Surgery, vol. 28, pp. 1526-1529, 2011.

[158] X.-D. Gai, C.-Q. Zeng, and M. Hong, "Effect of bupleurun Chinese DC(BCDC) on the MDR reversal of hepatocellular carcinoma and related mechanism," Chemical Journal of Chinese Universities, vol. 26, no. 8, pp. 1446-1450, 2005.

[159] F. H. Yang, Z. M. Wang, and X. L. Wu, "Grape seed polyphenols reverses multidrug resistance of GBC-SD cell lines," Chinese 
Journal of Current Advances in General Surgery, vol. 8, pp. 355357, 2005.

[160] H. F. Shi, H. F. Zhang, Q. Zhao, W. X. Zhao, and J. Dan, "Tea polyphenol overcomes drug resistance of HL60/VCR cells," Chinese Journal of Gerontology, vol. 31, pp. 258-261, 2011.

[161] Y. T. Shi, H. Jing, Y. Wang, J. L. Yi, and C. Y. Liu, "Rat serum containing of Buzhong yiqi decoction reverse chemotherapeutic resistance in A549/DDP cells by down-regulating expression levels of mTOR," Chinese Journal of Experimental Traditional Medical Formulae, vol. 19, pp. 215-218, 2013.

[162] W. K. Ma, Y. M. He, X. M. Yao, Y. Huang, Y. Wang, and Y. J. $\mathrm{Li}$, "Reverse effect of serum containing Jiedu huayu recipe on multidrug resistance of leukemia HL60/Adr cells," Traditional Chinese Drug Research \& Clinical Pharmacology, vol. 22, pp. 524-527, 2011.

[163] J. Li and P. P. Liu, "The study about Herba Scutellariae Barbatae reverse the drug resistance of leukemia cell line K562/A02," Guiding Journal of Traditional Chinese Medicine and Pharmacology, vol. 18, pp. 88-89, 2012.

[164] X. L. Zhang, T. Huang, X. F. Yang, L. Huang, and Y. Li, "Experimental studies on reversion effects of shehuang xiaoliu decoction on multidrug resistance of human hepatoma cells," Chinese Journal of Traditional Medical Science and Technology, vol. 21, pp. 25-27, 2014.

[165] S. F. Zhou, J. Chen, and M. Wang, "Reverse effect of zedoary turmeric oil serum on multidrug-resistant of stomach cancer cell line SGC7901/CDDP," Traditional Chinese Drug Research \& Clinical Pharmacology, vol. 23, pp. 508-511, 2012.

[166] C. Jiang and X. G. Yang, "Study on ligustrazine combined with chemotherapy in patients with relapsed or refractory nonHodgkin's lymphoma," Journal of International Oncology, vol. 37, pp. 397-400, 2010.

[167] X. C. Wang, "Multidrug resistance reversal effect of breast cancer by wuweizi dranule combined with CAF chemotherapy," Chinese Journal of Experimental Traditional Medical Formulae, vol. 20, pp. 241-243, 2014.

[168] J. H. Xu, Z. Z. Fan, J. Sun et al., "Effects of 'Chang Wei Qing' in treating advanced gastrointestinal cancer and its effects on peripheral blood MDR1 mRNA," Shanghai Journal of Traditional Chinese Medicine, vol. 41, pp. 40-42, 2007.

[169] H. L. Chen, X. L. Yang, and P. J. Yang, "Treatment of gastric cancer with Didang formula," China Health Industry, vol. 8, pp. 59-60, 2011.

[170] Y. X. Zhang, C. H. Li, W. G. Song, and L. Jiang, "Treatment of liver cancer using Xiaochaihu formula," Seek Medical and Ask the Medicine, vol. 11, pp. 486-487, 2013.

[171] P. Shu and S. L. Liu, "Clinical observation on reversal effects of multi-drug resistance gene and lung resistance protein in gastric cancer treated by shenqi jiangwei decoction," Hunan Journal of Traditional Chinese Medicine, vol. 24, pp. 1-2, 2008.

[172] C. Y. Huang, J. Q. Chen, Y. Shen, H. H. Xie, and X. Y. Nie, "Study on the effect of Pingxiao capsule on multidrug resistant gene P-gp, TOPOII and GST- $\pi$ for breast cancer," Lingnan Modern Clinics in Surgery, vol. 11, pp. 38-40, 2011.

[173] Q. J. Chen, R. Zhang, H. L. Situ et al., "Effects of Fukangling capsule on multidrug resistant geneprotein p170 and GST- $\pi$ of breast cancer," China Pharmacy, vol. 19, pp. 1650-1651, 2008.

[174] S. C. Zhang, X. Q. Zhang, F. W. Zhou, L. F. Yang, and X. J. Zhao, "Study of Qiankun capsule on mechanism of raising efficiency and reducing toxicity during chemotherapy in non-small cell lung cancer," Hebei Journal of Traditional Chinese Medicine, vol. 32, pp. 1448-1450, 2010. 


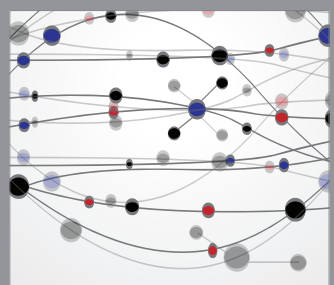

The Scientific World Journal
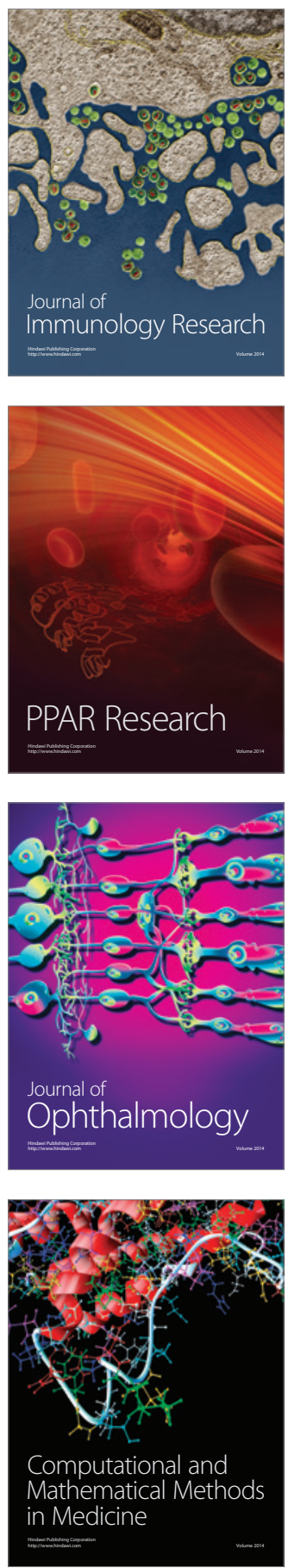

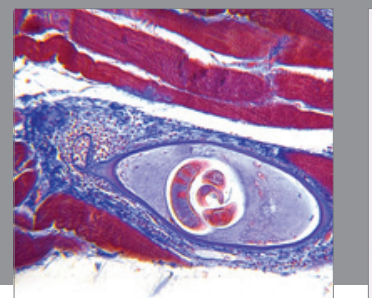

Gastroenterology

Research and Practice
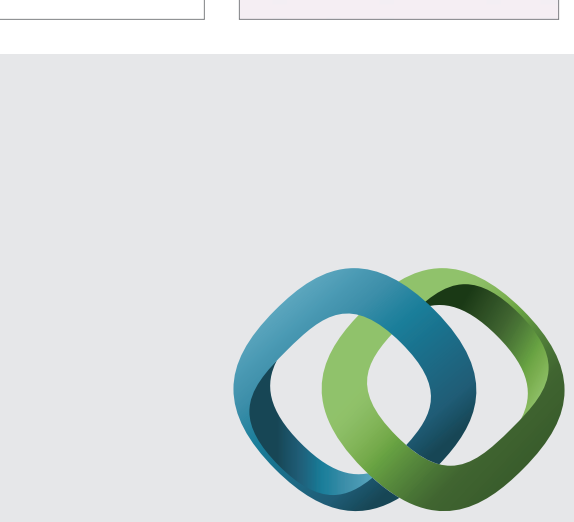

\section{Hindawi}

Submit your manuscripts at

http://www.hindawi.com
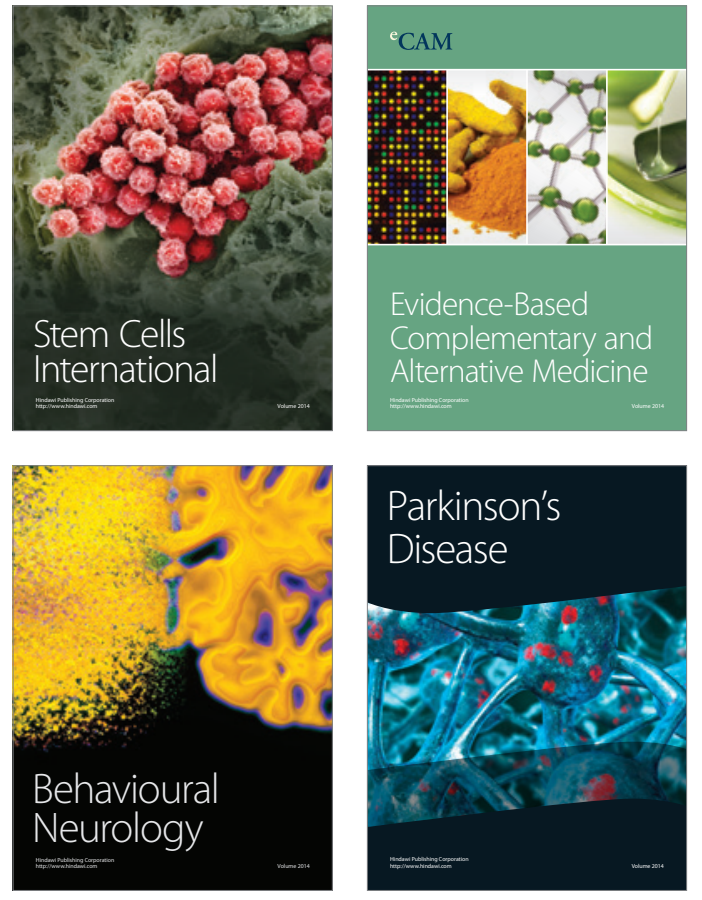
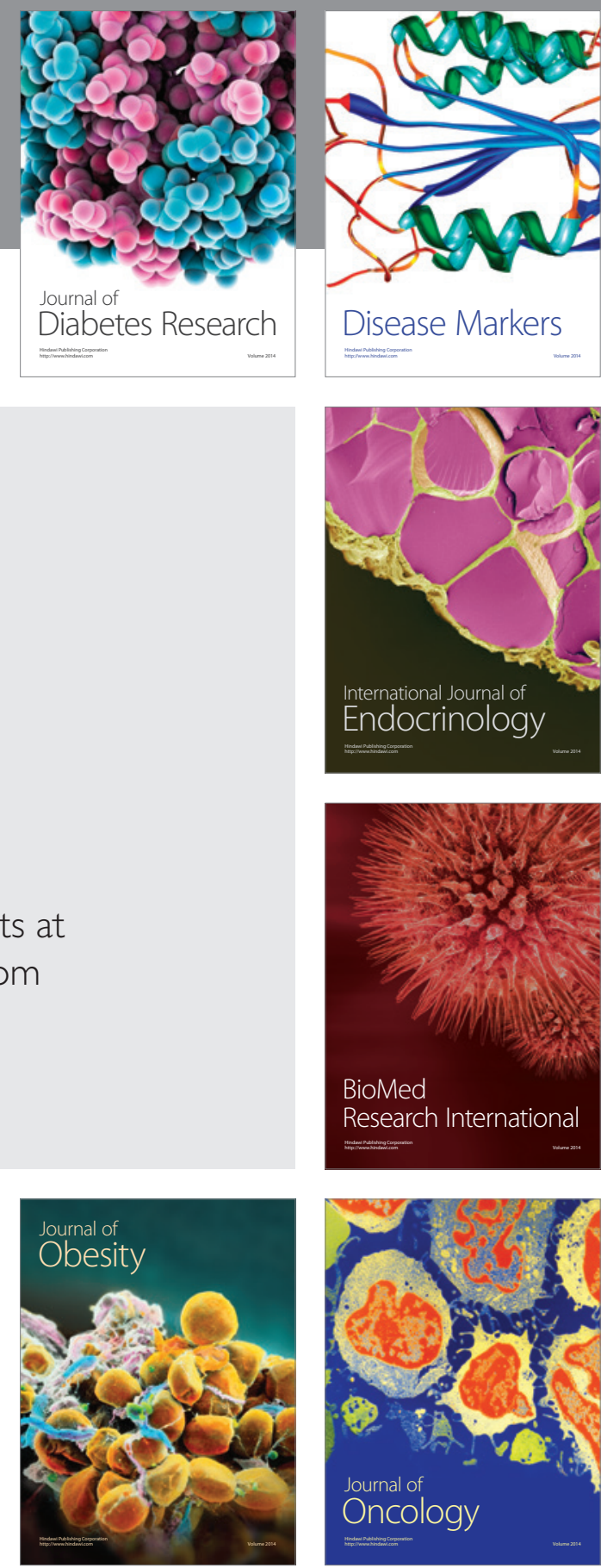

Disease Markers
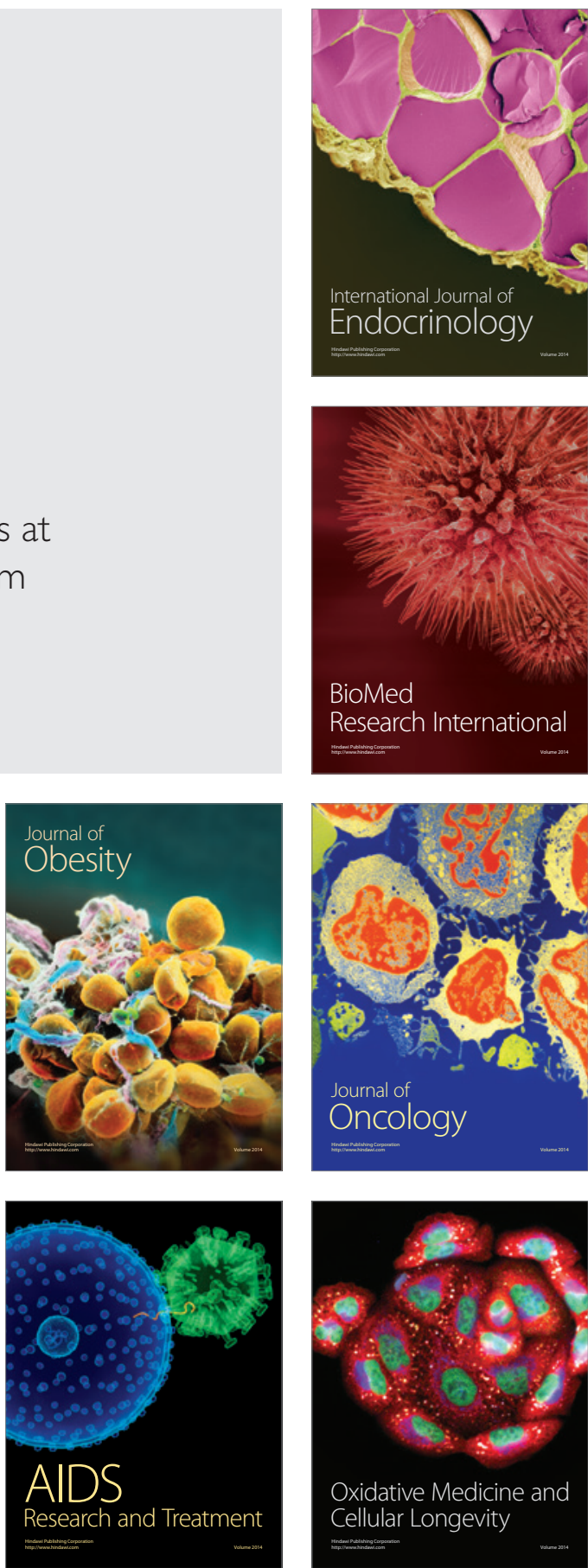